\title{
Faktor-Faktor yang Memengaruhi Kompetensi Penyuluh Narkoba dalam Penyuluhan Digital
}

\section{Factors Affecting the Competence of Anti-Narcotics Extension Agents in Digital Extension}

\author{
Afib Rizal ${ }^{1, *)}$, Anna Fatchiya ${ }^{2}$, Dwi Sadono ${ }^{2}$
}

${ }^{1}$ Badan Narkotika Nasional Provinsi DKI Jakarta, Jakarta 10150, Indonesia

${ }^{2}$ Departemen Sains Komunikasi dan Pengembangan Masyarakat, Institut Pertanian Bogor, Bogor 16680, Indonesia

${ }^{*}$ E-mail Korespondensi: afibrizal@apps.ipb.ac.id

Diterima: 23 Maret 2021 | Disetujui: 9 Agustus 2021 | Publikasi Online: 18 Agustus 2021

\begin{abstract}
Utilization of digital media for an extension is a solution the improvement of the competence of AntiNarcotics extension agents. This study aims to analyze the influence of the individual characteristics of the extension agents, patterns of digital media use, institutional support, and characteristics of innovation on the competence of Anti-Narcotics extension agents. This research was conducted in October 2020 - January 2021 through a census of 170 (98\%) functional officers of Anti-Narcotics extension agents throughout Indonesia who have worked for approximately two years. The research instruments were questions, statements (telephone and message), and interviews which were conducted using the digital application Google Form and WhatsApp. Data were processed using Partial Least Square. The results showed that the use of digital media by extension agents consisting of patterns of digital media use, characteristics of innovation, institutional support, and competence of Anti-Narcotics extension agents in the field of information and communication technology were in the Medium category. The competence of Anti-Narcotics extension agents in the use of digital media was in the medium category. This competence is influenced by factors of digital media utilization patterns, innovation characteristics, and institutional support.
\end{abstract}

Keywords: Extension agents, competency, digital media

\begin{abstract}
ABSTRAK
Pemanfaatan media digital untuk penyuluhan adalah solusi peningkatan kompetensi Penyuluh Narkoba. Penelitian ini bertujuan menganalisis pengaruh karakteristik individu penyuluh, pola pemanfaatan media digital, dukungan kelembagaan, dan karakteristik inovasi terhadap kompetensi Penyuluh narkoba. Penelitian ini dilaksanakan bulan Oktober 2020 - Januari 2021 melalui sensus kepada 170 (98\%) orang pejabat fungsional Penyuluh Narkoba di seluruh Indonesia yang memiliki masa kerja kurang lebih dua tahun. Instrumen penelitian berupa kuesioner pertanyaan, pernyataan, dan wawancara menggunakan aplikasi digital Google form dan WhatsApp (telepon dan pesan). Data diolah menggunakan Partial Least Square (PLS). Hasil penelitian menunjukkan, kompetensi Penyuluh Narkoba dalam pemanfaatan media digital berada dalam kategori sedang. Kompetensi ini dipengaruhi faktor pola pemanfaatan media digital, karakteristik inovasi, dan dukungan kelembagaan.
\end{abstract}

Kata kunci: Penyuluh, kompetensi, media digital

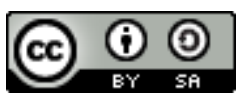

Content from this work may be used under the terms of the Creative Commons Attribution-ShareAlike

4.0 International. Any further distribution of this work must maintain attribution to the author(s) and the title of the work, journal citation and DOI.

Published under Department of Communication and Community Development Science, IPB University and in association with Perhimpunan Ahli Penyuluhan Pembangunan Indonesia.

E-ISSN: 2442-4110 | P-ISSN: 1858-2664 


\section{PENDAHULUAN}

Hasil survei Pusat Penelitian Data dan Informasi Badan Narkotika Nasional (2021) menunjukkan bahwa kelompok penyalahguna narkoba terbesar di Indonesia adalah berasal dari kelompok usia produktif. Rentang usia 17-19 tahun adalah kelompok pertama kali menggunakan narkoba dan target pasar utama peredaran narkoba dalam rentang umur 11-24 tahun. Tren prevalensi penyalahgunaan narkoba di Indonesia pada sektor pelajar dan mahasiswa secara keseluruhan pada tahun 2020 adalah sebesar 3,2\%, atau setara dengan 2.297.492 orang. Angka prevalensi pelajar SMA yang pernah pakai narkoba paling tinggi dibandingkan dengan pelajar SMP dan mahasiswa. Angka prevalensi pelajar SMA yang pernah pakai dan pernah memakai narkoba dalam satu tahun terakhir, sebesar $6,4 \%$ (pernah pakai narkoba) dan 3,5\% (pernah memakai narkoba dalam setahun ini). Angka prevalensi pelajar SMA ini menempati urutan teratas dibandingkan pelajar SMP dan mahasiswa (Puslitdatin BNN, 2020). Menurut Prasasti dan Prakoso (2020), rentang usia 15-34 tahun adalah generasi milenial yang melek teknologi digital.

Menyadari hal tersebut, Badan Narkotika Nasional (BNN) melakukan upaya pencegahan penyalahguna dan peredaran narkoba berbasiskan teknologi digital. Tindakan pencegahan dilakukan melalui penyuluhan modern (virtual) yang mengikuti perkembangan teknologi, informasi, dan komunikasi (TIK). Merujuk kepada Peraturan Kepala BNN RI Nomor 2 Tahun 2020 tentang Standar Kompetensi Penyuluh Narkoba, penyuluh narkoba harus memiliki kompetensi teknis yang berupa kemampuan penerapan metode, teknik, dan model penyuluhan narkoba yang mengikuti perkembangan zaman. Tuntutan ini mengingat penyuluh narkoba memiliki tugas, tanggungjawab, dan wewenang untuk melaksanakan penyuluhan narkoba dalam program Pencegahan dan Pemberantasan Penyalahgunaan dan Peredaran Gelap Narkoba (P4GN).

Penyuluhan menggunakan media virtual harus ditunjang adanya kemampuan literasi digital. Menurut Irhandayaningsih (2020), kemampuan literasi digital adalah kemampuan penggunaan dan pengelolaan sistem TIK. Wheeler (2012) mengidentifikasi elemen penting dalam dunia literasi digital diantaranya adalah jejaring sosial, produksi konten, mengatur dan berbagi konten, menggunakan kembali / mengubah tujuan konten, menyaring dan memilih konten, serta menyiarkan diri. Senada dengan hal tersebut dalam penelitian ini, kompetensi literasi digital digunakan untuk mengukur indikator kompetensi pemanfaatan media digital oleh penyuluh narkoba.

Menurut Muslihat et al., (2015) dan Euriga et al. (2018), kompetensi adalah segala bentuk motif, sikap, keterampilan, perilaku atau karakteristik pribadi yang penting untuk melaksanakan pekerjaan atau membedakan antara kinerja rata-rata dengan kinerja superior. Merujuk Peraturan Menteri Pemberdayaan Aparatur Negara dan Reformasi Birokrasi Nomor 46 Tahun 2014 Tentang Penyuluh Narkoba, penyuluhan adalah kegiatan diseminasi Pencegahan dan Pemberantasan Penyalahgunaan dan Peredaran Gelap Narkoba (P4GN). Penyuluhan digital dilakukan melalui pembuatan konten P4GN yang disesuaikan dengan sasaran lingkungan pekerja, masyarakat, pendidikan, keluarga, dan kesehatan. Posisi ini menempatkan penyuluh narkoba berfungsi sebagai juru penerang (Siswanto, 2012)dan agen perubahan pemerintah (Syahyuti, 2014).

Fasilitasi yang dilakukan BNN dengan mengeluarkan Surat Edaran Kepala BNN Nomor SE/83/VI/KA/KP.10/2020/BNN Tahun 2020 Tentang Penyelenggaraan Sosialisasi P4GN dan Pencegahan Penyebaran Virus Covid-19 di Lingkungan BNN Secara Daring. Tindak lanjut Surat Edaran tersebut adalah kewajiban penyuluh narkoba melaksanakan penyuluhan digital minimal satu kali dalam seminggu. Situasi ini menempatkan penyuluh bekerja keras meningkatkan inovasi layanan penyuluhan (Ghimire, 2016). Sebaliknya penyuluh kurang berfungsi jika tidak berusaha meningkatkan kompetensi (Sumardjo, 2019).

Penyuluh sebagai diseminator inovasi seharusnya dapat memproduksi konten kreatif di media digital sebagai tontonan yang menarik maupun tuntunan bagi khalayak yang mengaksesnya. Output keberhasilan penyuluhan narkoba adalah berhubungan dengan jumlah sebaran informasi yang disampaikan kepada masyarakat melalui penyuluhan. Artinya penyuluh dianggap semakin produktif apabila jumlah kegiatan penyuluhan yang telah dilakukan banyak. Tolok ukur keberhasilan secara Outcome adalah jumlah masyarakat yang memiliki imunitas dan resiliensi terkait tawaran 
penyalahgunaan dan peredaran gelap narkoba. Jumlah penyuluh yang terbatas dan rendahnya kompetensi penyuluh (Kustiari et al., 2017) terutama dalam penyuluhan digital adalah tantangan untuk menuju keberhasilan tersebut.

Penyuluhan digital memiliki keuntungan jika dibandingkan dengan penyuluhan konvensional yaitu ; (1) mudah diingat khalayak, (2) dapat diputar berulang kali di telepon pintar atau komputer, (3) dapat menghindari formalitas dalam penyuluhan, dan (4) meminimalisir pembiayaan (Non DIPA) karena proses produksi cukup mengandalkan kestabilan jaringan internet. Sampai pertengahan tahun 2020, pelaksanaan penyuluhan digital oleh penyuluh belum berjalan secara efektif karena diduga terdapat kendala internal maupun eksternal. Padahal keterdedahan para penyuluh yang mengenal internet lewat telepon pintar ataupun komputer sudah cukup baik. Fakta ini sesuai dengan hasil penelitian Akpotosu et al. (2017), dimana penyuluh memanfaatkan internet untuk kepentingan dirinya sendiri seperti mencari informasi yang sifatnya pribadi. Praktek ini dapat menghambat profesionalisme penyuluh (Mardikanto, 2009) dan menimbulkan penyimpangan filosofis penyuluhan karena dilakukan oleh mereka yang kurang memiliki kompetensi (Sumardjo, 2010). Hasilnya konten digital dibuat sekedar publikasi dan dokumentasi kegiatan kantor, kurangnya kreatif, belum sesuai kebutuhan klien, waktu penyajian yang kurang tepat, dan tidak ada unsur keperbaruan. Efeknya adalah sistem umpan balik dari khalayak yang mengunjungi situs digital tidak berjalan optimal.

Menghadapi permasalahan tersebut seharusnya rekrutmen penyuluh ditujukan kepada individu yang berkompeten (Baig dan Aldosari, 2013) sesuai dengan persyaratan minimal jabatan (Fatchiya, 2010) dan adanya revitalisasi peran penyuluh (Sumardjo, 2017). Hal ini dikarenakan keberhasilan adopsi model penyebaran informasi modern tergantung kepada penyuluh (Zhang et al., 2016), sehingga klien tidak menyalahkan penyuluh yang tidak memiliki inovasi (Ngomane, 2010).

Hasil penelitian terdahulu terkait pemanfaatan media digital yang dilakukan oleh penyuluh antara lain; pemanfaatan media komunikasi cyber extension (Mulyandari et al., 2010), penggunaan internet untuk memperoleh informasi pertanian oleh penyuluh pertanian (Elian et al., 2014), pemanfaatan internet oleh penyuluh (Veronice et al., 2015), kompetensi penyuluh memanfaatkan internet (Akpotosu et al., 2017), pemanfaatan media sosial Facebook dalam penyuluhan pertanian dan perikanan (Prayoga, 2018), pemanfaatan internet dalam meningkatkan kinerja penyuluh pertanian (Purwatiningsih et al., 2018), kinerja penyuluh pertanian dalam pemanfaatan cyber extension (Sabir et al., 2018), optimalisasi cyber extension dalam pembangunan pertanian (Praza, 2016), pemanfaatan internet untuk penyuluhan (Kenneth et al., 2019), pengaruh dukungan lembaga dan pemanfaatan media sosial terhadap peningkatan kompetensi penyuluh (Humaidi et al., 2020), dan pemanfaatan media sosial untuk penyuluhan (Suratini et al., 2021). Hasil-hasil penelitian tersebut mengungkapkan keterkaitan pemanfaatan internet, cyber extension, dan media sosial secara umum untuk penyuluhan pertanian.

Pada hakekatnya penyuluhan digital diberikan sebagai upaya memelihara dan mengembangkan kemampuan serta kesiapan penyuluh dalam melaksanakan segala bentuk tugas maupun tantangan kerja yang dihadapinya. Berdasarkan pernyataan di atas, penelitian ini bertujuan untuk (1) mendeskripsikan karakteristik individu penyuluh, pola pemanfaatan media digital, karakteristik inovasi, dukungan kelembagaan, dan kompetensi penyuluh narkoba. (2) menganalisis faktor-faktor yang memengaruhi kompetensi penyuluh narkoba dalam penyuluhan digital.

\section{METODE PENELITIAN}

Penelitian ini berbentuk deskriptif menggunakan metode sensus yang dilaksanakan pada bulan Oktober 2020 - Januari 2021 kepada 170 orang (98\%) dari total 174 orang penyuluh narkoba di seluruh BNN provinsi maupun BNN kabupaten/kota seluruh Indonesia yang memiliki masa kerja sebagai penyuluh narkoba kurang lebih 2 tahun. Data hasil penelitian kuantitatif diperkuat dengan data kualitatif. Instrumen penelitian berupa kuesioner berisikan pertanyaan dan pernyataan, serta wawancara mendalam. Peneliti mengumpulkan data melalui penyebaran kuesioner menggunakan aplikasi digital google form dan WhatsApp (telepon dan teks pesan).

Peubah bebas dalam penelitian ini terdiri dari : (1) Karakteristik individu $\left(\mathrm{X}_{1}\right)$ diukur Menggunakan skala rasio terdiri dari: umur (Muda, Dewasa, Tua), masa kerja sebagai penyuluh (Baru $<3$ tahun, Sedang 4-5 tahun, Lama $>5$ tahun), jumlah diklat yang pernah diikuti dikelompokkan menjadi tiga kategori (rendah 0-1 kali, sedang 2 kali, tinggi $>2$ kali). (2) Pola pemanfaatan media digital $\left(\mathrm{X}_{2}\right)$ terdiri 
dari : durasi, frekuensi, keragaman TIK, dan biaya akses. (3) Karakteristik inovasi $\left(\mathrm{X}_{3}\right)$ terdiri dari : keuntungan relatif, kompatibel, kompleksitas, Trialabilitas, dan observabilitas. (4) Peubah dukungan kelembagaan $\left(\mathrm{X}_{4}\right)$ terdiri dari: iklim kerja dan dukungan atasan. Variabel terikat penelitian ini adalah (1) kompetensi penyuluh (Y) terdiri dari : pengetahuan, keterampilan, dan sikap.

Untuk mengukur rataan indikator menggunakan rumus transformasi indeks indikator (Sumardjo, 1999). Data kuantitatif dari hasil di lapangan kemudian ditransformasikan ke dalam bentuk ordinal dengan skala 0-100. Transformasi indeks menggunakan rumus :

Indeks Indikator

$$
\begin{gathered}
=\sum \text { Skor Indikator yang dicapai }-\sum \text { Skor Indikator Minimal } \\
\sum \text { Skor Indikator Maksimal }-\sum \text { Skor Indikator Minimal } \\
\text { Indeks Peubah }=\text { Indeks Indikator }: \text { Indeks rata-rata }
\end{gathered}
$$

Skor dikelompokkan menjadi tiga jenjang tingkatan yaitu $0-33,33=$ rendah, 33,34 - 66,66 = sedang, dan $66,67-100=$ tinggi untuk keperluan interpretasi data.

Uji validitas dan reliabilitas dalam penelitian ini menggunakan aplikasi SPSS versi 25 kepada 35 (tiga puluh lima) orang penyuluh narkoba yang belum diangkat dalam jabatan fungsional. Pemilihan ini dengan mempertimbangkan keragaman penyuluh dilihat dari lokasi kerja kabupaten-kota, Jawa-luar Jawa, serta unsur umur. Alasan pemilihan responden uji validitas dan reliabilitas ini adalah karena para penyuluh narkoba tersebut memiliki karakteristik yang sama dengan responden penelitian. Hasil uji validitas tergolong valid, karena nilai $r$ hitung $0,341^{*}-0,864^{* *}>\mathrm{r}$ Tabel 0,334 pada taraf nyata 5 persen. Hasil Uji reliabilitas menggunakan uji reliabilitas internal konsistensi menggunakan Cronbach's Alpha menghasilkan angka 0,810 - 0,855 (sangat reliabel). Penyajian data ditampilkan dalam bentuk Tabel frekuensi dan diagram batang. Aplikasi Smart PLS3.2.9. digunakan untuk melakukan pengujian terhadap model pengukuran (measurement model) dan model struktural (structural model). Data lengkap dapat dilihat dalam Gambar 1.

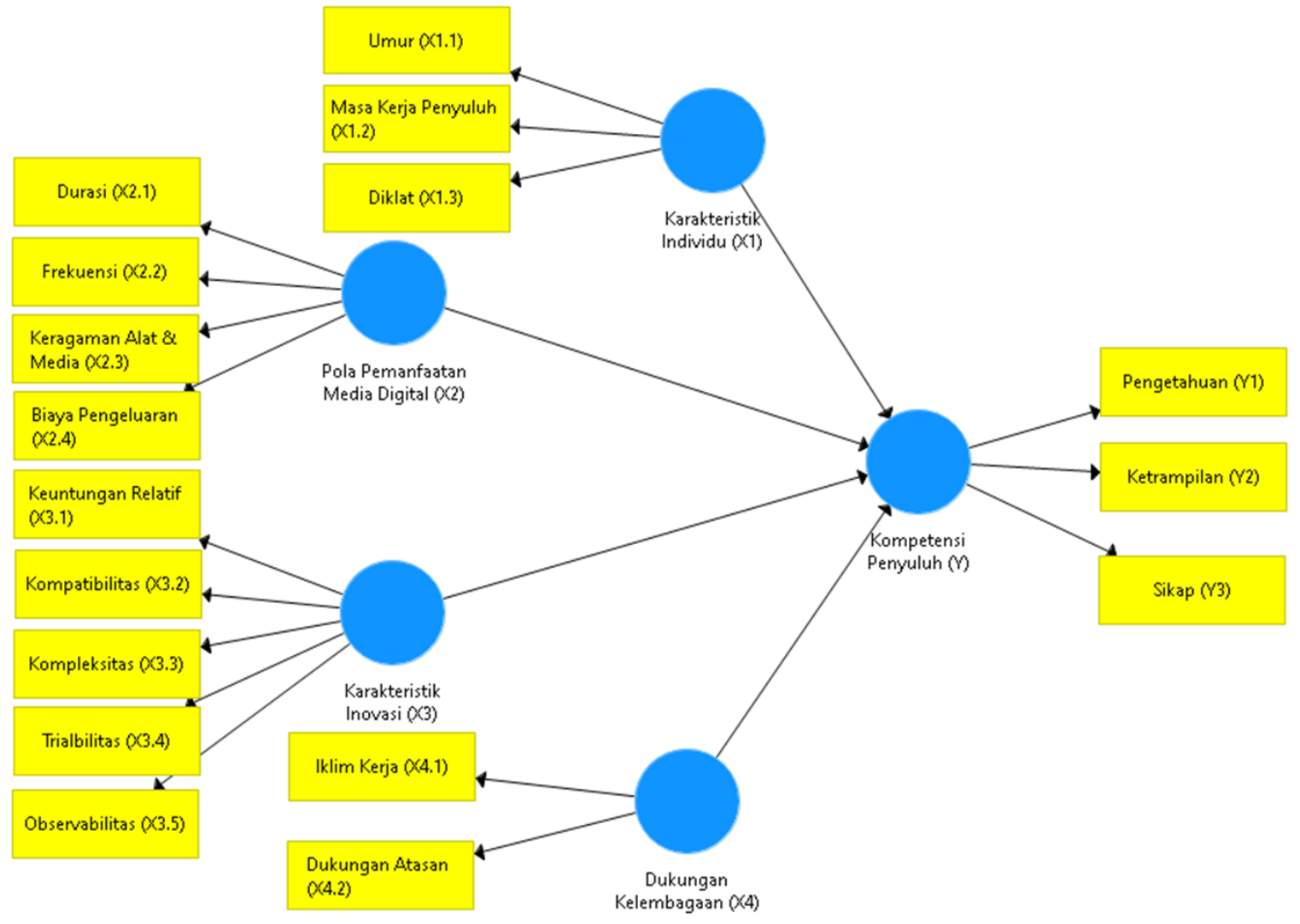

Gambar 1. Model hipotetik persamaan struktural variabel penelitian 


\section{HASIL DAN PEMBAHASAN}

\section{Karakteristik Individu Penyuluh}

Karakteristik individu penyuluh merupakan bagian dari ciri pribadi yang melekat pada diri seorang penyuluh yang membedakan dengan penyuluh lain. Karakteristik ini didasari tingkah laku seseorang dalam situasi kerja maupun situasi yang lainnya. Karakteristik individu penyuluh dalam penelitian terdiri dari: umur, pengalaman kerja sebagai penyuluh, dan diklat yang pernah diikuti (Tabel 1).

Tabel 1. Karakteristik Individu Penyuluh Narkoba

\begin{tabular}{llcc}
\hline \multicolumn{1}{c}{ Sub Variabel } & \multicolumn{1}{c}{ Kategori } & N (Orang) & Persentase (\%) \\
\hline Umur (tahun) & Muda (24-35 tahun) & 127 & 74,71 \\
Rataan umur 33 & Dewasa (36-47 tahun) & 39 & 26 \\
& Tua (48-57 tahun) & 4 & 2,3 \\
\hline Masa Kerja Penyuluh & Baru (1-3 tahun) & 85 & 38,82 \\
Rataan tahun 4 & Sedang (4-5 tahun) & 4 & 28,85 \\
& Lama (>5 tahun) & 81 & 43,53 \\
\hline Jumlah Diklat & rendah (0-1 kali) & 110 & 64,71 \\
Rataan Mengikuti 1 & sedang (2 kali) & 42 & 24,71 \\
& tinggi (>2 kali) & 18 & 10,59 \\
\hline
\end{tabular}

Berdasarkan Tabel 1, umur penyuluh narkoba berkisar antara 24-58 tahun. Rataan umur 33 tahun membuktikan bahwa penyuluh narkoba berada dalam kategori umur produktif (15-55 tahun). Artinya penyuluh memiliki kemampuan dalam mempelajari, memahami, menerima, dan mengadopsi suatu teknologi serta peningkatan kompetensi. Hasil penelitian ini berbeda dengan temuan penelitian yang dilakukan oleh Pramono et al. (2017), Bahua (2018), Wijaya et al. (2019), dan Figna et al. (2019) yang menunjukkan bahwa umur penyuluh pertanian mayoritas berusia di atas 40 tahun yang pada akhirnya menyebabkan penurunan kemampuan dalam penggunaan media digital untuk penyuluhan. Hal ini berarti semakin dewasa seorang penyuluh akan semakin meningkat kinerjanya, tetapi jika sudah melewati masa produktif maka kompetensi akan cenderung menurun.

Tabel 1 menunjukkan bahwa sebagian penyuluh memiliki masa kerja yang lama dan sebagian lain memiliki masa kerja yang baru. Masa kerja yang lama akan memengaruhi kompetensi penyuluh dalam melakukan aktivitasnya. Semakin lama seorang penyuluh menjalani tugasnya akan berbanding lurus dengan kemampuannya dalam hal-hal teknis berkaitan dengan penyuluhan (Hubeis, 2007). Sebaliknya seorang yang memiliki masa kerja yang relatif baru akan sering mengalami kecanggungan dalam urusan teknis penyuluhan seperti pemanfaatan perangkat teknologi. Hal ini disebabkan oleh berkembangnya kemampuan serta pola pikir dalam melakukan aktifitas penyuluhan. Penyuluh yang memiliki masa kerja lama berasal dari pengangkatan pertama rekrutmen CPNS tahun 2012 dan 2014. Penyuluh yang memiliki masa kerja dalam kategori baru adalah hasil rekrutmen CPNS tahun 2015 dan 2018, serta hasil redistribusi pegawai.

Merujuk Pasal 203 Peraturan Pemerintah Republik Indonesia Nomor 11 Tahun 2017 Tentang Manajemen Pegawai Negeri Sipil (PNS), disebutkan bahwa setiap PNS memiliki hak dan kesempatan yang sama untuk diikutsertakan dalam pengembangan kompetensi. Berdasarkan hasil wawancara, rendahnya diklat yang pernah diikuti karena kesempatan untuk mengikuti diklat terbatas dan jenis diklat yang diselenggarakan belum sesuai dengan kebutuhan penyuluh. Kesempatan mengikuti diklat akan semakin besar jika di dalam satuan kerja penyuluh bersangkutan memiliki jumlah penyuluh sedikit. Sebagian besar penyuluh yang menyebutkan pernah mengikuti diklat adalah diklat dasar fungsional penyuluh narkoba. 


\section{Pola Pemanfaatan Media Digital}

Media digital dianggap mampu merepresentasikan agenda khalayak yang memiliki pengaruh terhadap agenda media. Internet tidak hanya memperluas cakupan dinamika agenda-setting namun juga memperluas definisi 'sumber berita' dan 'redaksi pemberitaan' di dalam proses komunikasi massa (Sayre et al., 2010). Pemanfaatan media digital oleh penyuluh sangat penting karena sasaran utama program pencegahan penyalahgunaan narkoba lebih menyasar kawula muda. Hal ini karena penyuluh merupakan ujung tombak pelaksanaan penyuluhan (Anwas et al., 2010) dan wajib mengembangkan diri bagi khalayak sasaran (Prayoga, 2018). Penyampaian pesan digital kepada khalayak merupakan dinamika proses pelaporan yang dapat membentuk agenda kebijakan publik (Groshek dan Groshek, 2013). Fenomena ini mengindikasikan bahwa media digital bisa menjadi gambaran kecenderungan agenda khalayak yang bisa berorientasi kepada sikap dan perilaku sosial masyarakat (Prabowo dan Irwansyah, 2018). Media digital pada akhirnya telah mengaburkan batasan (media, khalayak, dan agenda) sehingga memunculkan apa yang disebut Castells (2009) sebagai mass-self communication (individu menjadi media baru tanpa batas).

Pemanfaatan media digital oleh penyuluh adalah intensitas akses media digital atau gambaran berapa lama dan intensitas memanfaatkan media digital untuk penyuluhan dalam kurun waktu tertentu. Durasi pemanfaatan media digital adalah lamanya waktu yang digunakan untuk penyuluhan setiap hari. Frekuensi memanfaatkan media digital adalah intensitas pemanfaatan media digital untuk penyuluhan dalam seminggu. Rendahnya durasi dan frekuensi pemanfaatan media digital menjadi salah satu penghambat implementasi dari E-government (Mulyandari et al., 2010).

Tabel 2. Pola Pemanfaatan Media Digital oleh Penyuluh Narkoba, 2021

\begin{tabular}{lcc}
\hline \multicolumn{1}{c}{ Sub Variabel } & Rataan & Kategori \\
\hline Durasi & 18,33 & Rendah \\
Frekuensi & 30,54 & Rendah \\
Keragaman TIK & 53,79 & Sedang \\
Biaya Pengeluaran & 47,87 & Sedang \\
\hline Rataan Peubah & 37,63 & Sedang \\
\hline
\end{tabular}

Berdasarkan hasil penelitian pada Tabel 2, seluruh penyuluh adalah pengguna media digital aktif meskipun dengan intensitas dan keragaman media yang berbeda-beda. Penyuluh yang kurang aktif memanfaatkan media digital adalah penyuluh yang berlokasi kerja di daerah terpencil, terluar, dan tertinggal. Secara umum pola pemanfaatan media digital oleh penyuluh narkoba berada dalam kategori sedang (rataan 37,63). Artinya, penyuluh memiliki kecukupan dalam menggunakan media digital untuk penyuluhan digital.

Durasi memanfaatkan media digital diukur dalam satuan waktu jam per hari dan berada dalam kategori rendah (Tabel 2). Hal ini karena rutinitas penyuluh dalam memanfaatkan media digital masih sebatas mengunggah dan menyebarkan konten yang memerlukan waktu kurang dari 1 jam, sedangkan proses produksi konten masih banyak yang menggunakan aplikasi offline. Penyuluh juga belum memanfaatkan media digital untuk pencarian informasi tambahan ataupun interaksi antara penyuluh dengan klien. Temuan penelitian ini sejalan dengan penelitian yang dilakukan oleh Elian, Lubis, Rangkuti, et al., (2014) dan (Suratini et al., 2021).

Durasi media digital yang rendah pemanfaatannya adalah Twitter dan Youtube (Tabel 3). Twitter memiliki kelemahan mendasar yaitu (1) terbatas jumlah penulisan yang kurang lebih 280 huruf, (2) video yang bisa diunggah kurang dari 2 menit 30 detik, dan (3) segmentasi pengguna bukan kaum milienial. Akun WhatsApp dimiliki oleh seluruh penyuluh namun kurang begitu optimal durasi penggunaan untuk penyuluhan dan hanya digunakan untuk perencanaan penyuluhan (koordinasi dan bertukar informasi). 
Tabel 3. Durasi dan Frekuensi Pemanfaatan Media Digital oleh Penyuluh Narkoba

\begin{tabular}{lccccccccccccc}
\hline \multirow{2}{*}{$\begin{array}{c}\text { Tingkat } \\
\text { Pemanfaatan }\end{array}$} & $\begin{array}{c}\text { FB } \\
\text { (N) }\end{array}$ & $\%$ & $\begin{array}{c}\text { WA } \\
\text { (N) }\end{array}$ & $\%$ & $\begin{array}{c}\text { TW } \\
(\mathbf{N})\end{array}$ & $\%$ & $\begin{array}{c}\text { IG } \\
(\mathbf{N})\end{array}$ & $\%$ & $\begin{array}{c}\text { YT } \\
(\mathbf{N})\end{array}$ & $\%$ & $\begin{array}{c}\mathbf{Z} \\
(\mathbf{N})\end{array}$ & $\%$ \\
\hline Durasi & & & & & & & & & & & & \\
0 jam & 84 & 49,41 & 66 & 38,82 & 134 & 78,82 & 30 & 17,65 & 107 & 62,94 & 86 & 50,59 \\
1-3 jam & 83 & 48,82 & 93 & 54,71 & 34 & 20,00 & 120 & 70,59 & 62 & 36,47 & 82 & 48,24 \\
4-6 jam & 1 & 0,59 & 9 & 5,29 & 0 & 0,00 & 17 & 10,00 & 1 & 0,59 & 2 & 1,18 \\
$>$ 7 jam & 2 & 1,18 & 2 & 1,18 & 2 & 1,18 & 3 & 1,76 & 0 & 0,00 & 0 & 0,00 \\
Frekuensi & & & & & & & & & & & & \\
0 kali & 59 & 34,71 & 45 & 26,47 & 128 & 75,29 & 21 & 12,35 & 101 & 59,41 & 75 & 44,12 \\
1-2 kali & 58 & 34,12 & 64 & 37,65 & 26 & 15,29 & 56 & 32,94 & 54 & 31,76 & 88 & 51,76 \\
3-4 kali & 62 & 36,47 & 39 & 22,94 & 10 & 5,88 & 53 & 31,18 & 10 & 5,88 & 7 & 4,12 \\
$>$ 5 kali & 21 & 12,35 & 22 & 12,94 & 6 & 3,53 & 40 & 23,53 & 5 & 2,94 & 0 & 0,00 \\
\hline
\end{tabular}

Keterangan: $\mathrm{FB}=$ Facebook, WA= WhatsApp, TW= Twitter, IG= Instagram, YT= Youtube, Z=Zoom

$\mathrm{N}=$ Jumlah Orang, \%=Persentase

Frekuensi memanfaatkan media digital adalah tingkat intensitas penyuluh memanfaatkan media digital untuk melakukan penyuluhan dalam rentang waktu satu minggu. Penelitian ini mengkaji enam media digital yang sering digunakan oleh penyuluh yaitu Facebook, Youtube, WhatsApp, Twitter, Zoom, dan Instagram. Tabel 3 menunjukkan bahwa frekuensi pemanfaatan media digital oleh penyuluh berada dalam kategori rendah. Hasil penelitian ini sama dengan penelitian yang dilakukan oleh Elian et al. (2014) dan Suratini et al. (2021) yang menemukan fakta bahwa digitalisasi penyuluhan bukan pekerjaan utama penyuluh, karena kegiatan utama penyuluh adalah melakukan kunjungan ke petani maupun kelompok tani yang dilakukan hampir setiap hari.

Frekuensi media digital yang sering dimanfaatkan penyuluh adalah aplikasi webinar terutama Zoom (Tabel 3). Keunggulan Zoom dapat menyebarkan pelaksanaan webinar dalam waktu bersamaan dengan Facebook, Instagram, dan Youtube. Hasil pengamatan di lapangan menunjukkan, frekuensi pemanfaatan media digital lebih cenderung terkait wilayah kerja penyuluh narkoba yang menerapkan Pembatasan Sosial Berskala Besar (PSBB) di masa pandemi. Semakin lama PSBB dilaksanakan terutama dalam kegiatan belajar mengajar dan Work From Home, maka akan berbanding lurus dengan banyaknya penyuluhan menggunakan Zoom Webinar. Sebaliknya semakin sedikit PSBB dilaksanakan ataupun daerah tersebut memperbolehkan kegiatan belajar mengajar di sekolah, maka penggunaan Zoom untuk webinar juga semakin rendah. Hasil penelitian ini berbeda dengan Penelitian yang dilakukan oleh Elian et al. (2014) dan Veronice (2015) yang menyatakan tinggi rendahnya frekuensi pemanfaatan internet berkaitan dengan faktor umur.

Penyuluh memilih media yang sesuai untuk mendukung tugasnya dengan pertimbangan peranan dan penggunaannya secara efektif. Keragaman alat dan media digital yang digunakan oleh penyuluh sangat bervariasi yang berada dalam kategori sedang (Tabel 4). Telepon pintar dimiliki oleh seluruh penyuluh, namun ada penyuluh yang hanya memanfaatkan untuk komunikasi dan hiburan (14 orang). Keberadaan telepon pintar adalah seperti komputer di dalam genggaman tangan, karena banyak aplikasi website banyak yang telah diubah oleh pengembang menjadi tampilan mobile. Mobilitas penyuluh yang tinggi sangat ditunjang oleh telepon pintar yang dimiliki. Berbeda dengan telepon pintar, pemanfaatan laptop dan komputer (desktop) tidak bisa digunakan untuk mendukung mobilitas penyuluh karena tidak tersedianya sim card di dalamnya untuk mengakses jaringan internet. Perangkat komputer desktop yang masih digunakan oleh penyuluh merupakan inventaris dari kantor sehingga pemanfaatannya hanya pada hari dan jam kerja kantor. 
Tabel 4. Keragaman Alat Digital oleh Penyuluh Narkoba

\begin{tabular}{lcc}
\hline \multicolumn{1}{c}{ Alat } & N (Orang) & Persentase (\%) \\
\hline Telepon pintar & 156 & 37,96 \\
Laptop & 153 & 37,23 \\
Komputer & 73 & 17,76 \\
Smart TV & 29 & 7,06 \\
\hline
\end{tabular}

Smart TV (Televisi Pintar) atau yang biasa disebut komputer TV merupakan teknologi baru televisi yang dapat tersambung dengan internet. Kepemilikan TV pintar ini masih terbatas dan hanya dimiliki oleh mereka yang berlangganan paket wifi rumah saja. Mahalnya harga dan fungsinya mirip dengan komputer dengan ukuran besar menjadi salah satu kelemahan Smart TV untuk bisa dimanfaatkan sebagai media penyuluhan. Tidak semua satuan kerja BNN Provinsi dan BNN Kabupaten/kota memiliki Smart TV yang merupakan inventaris kantor, dan pemanfaatannya juga masih sebagai media hiburan. Padahal menurut Kurniawan (2016), Smart TV adalah pusat media pribadi bagi pemiliknya yang bisa berkomunikasi dengan dunia melalui sambungan internet.

Ketersediaan informasi melalui internet membantu proses penyuluhan lebih cepat dan efektif (Ahuja, 2011) karena didukung adanya video dan suara secara real-time sehingga terjadi interaksi secara digital dari Penyuluh dan klien (Zhang et al., 2016). Instagram merupakan aplikasi intensitasnya yang paling banyak dimanfaatkan untuk penyuluhan. Penggunaan Instagram yang menonjol adalah untuk membangun relasi sosial yang hangat, kebutuhan untuk mendapatkan kesenangan dan suka cita (Rahardjo et al. 2020). Instagram memiliki keunggulan terutama dalam hal posting dan sharing foto serta video dengan kualitas yang baik antar sesama pengguna.

WhatsApp adalah aplikasi yang dimiliki oleh seluruh penyuluh, namun pengoptimalan fungsinya lebih banyak untuk berkomunikasi, berinteraksi, dan berkoordinasi dalam merencanakan kegiatan penyuluhan maupun mempublikasikan berbagai kegiatan yang telah dilaksanakan di lapangan. Gambar 2 menunjukkan, hanya 19,63\% penyuluh yang memanfaatkan WhatsApp untuk kegiatan penyuluhan. Menurut Rahardjo et al. (2020), pemanfaatan WhatsApp cenderung untuk kegiatan meningkatkan kompetensi antara sesama pengguna (penyuluh narkoba). WhatsApp dianggap lebih mampu memenuhi kebutuhan akan kompetensi, kedekatan, harga diri, dan popularitas. WhatsApp juga digunakan sebagai sumber belajar mandiri meskipun mayoritas penyuluh adalah pembaca pasif (silent reader) di dalam grup-grup WhatsApp yang mereka ikuti. Hasil wawancara mengungkapkan, sikap ini dikarenakan (1) munculnya perasaan kurang keterdekatan antar sesama penyuluh, (2) wacana yang didiskusikan tidak menarik menurut mereka, dan (3) merasa tidak menyangkut urusan pribadi masingmasing. Kelemahan aplikasi WhatsApp adalah fitur video call hanya dapat dilakukan dengan jumlah peserta maksimal 8 (delapan) orang. Fitur ini berbeda dengan platform media digital lain seperti Youtube maupun zoom yang lebih mampu untuk penyuluhan dengan jumlah peserta banyak.

Pengoptimalan Youtube masih sebatas sebagai hiburan, posting video webinar live, dan tayangan rutinitas kegiatan kantor. Informasi terkait narkoba dari dalam negeri yang ada di Youtube mayoritas adalah konten yang diproduksi oleh BNN atau kegiatan BNN yang sebelumnya sudah beredar di grupgrup WhatsApp, sehingga penyuluh kurang begitu tertarik untuk mengoptimalkannya. Proses produksi yang lama dan rumit membuat Youtube kurang begitu dimanfaatkan untuk kegiatan penyuluhan.

Media digital yang paling banyak digunakan oleh penyuluh untuk penyuluhan adalah Instagram $(25,46 \%)$. Penggunaan Instagram untuk pemenuhan kebutuhan membangun relasi sosial yang hangat, mendapatkan kesenangan (Rahardjo et al. 2020) yang identik dengan ciri kaum milenial. Sebagai platform media digital, Instagram memiliki keunggulan terutama dalam hal posting dan sharing foto dan video dengan kualitas yang baik antar sesama penggunanya. Hampir sama dengan Twitter, Instagram memiliki timeline yang berjalan sangat cepat. Instagram memberikan wadah bagi penggunanya untuk dapat mencari berbagai macam informasi, menambah ilmu pengetahuan, berbagi foto dan video. Menurut Sakti dan Yulianto (2018) dalam mengkontruksi identitas diri, remaja memilah dan memilih gambaran diri yang akan dibentuk dalam Instagram. Keragaman media digital disajikan lengkap dalam Gambar 2. 


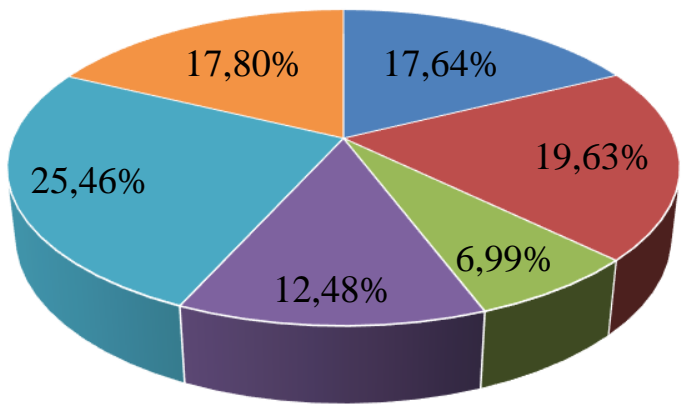

- Facebook " WhatsApp $\quad$ Twitter $\quad$ Youtube "Instagram "Zoom

Gambar 2. Keragaman Media Digital oleh Penyuluh Narkoba, 2021

Menurut Mulyandari et al. (2010) dan Sumardjo (2017), biaya adalah salah satu faktor pembatas untuk diadopsinya teknologi informasi dan komunikasi. Keragaman biaya yang dikeluarkan oleh penyuluh untuk membeli paket data dikarenakan keragaman harga paket data provider yang digunakan dan kebutuhan pemakaian setiap bulan. Sebagian besar penyuluh mengeluarkan biaya sampai dengan Rp. 200.000 ,- yang digunakan untuk pembelian paket data. Penyuluh yang tidak mengeluarkan biaya sama sekali untuk membeli paket data setiap bulan adalah berkaitan dengan privasi atau mendapat jatah paket data. Mereka menganggap akan terganggu jika banyak pemberitahuan notifikasi dari telepon pintarnya setiap saat di luar waktu kerja, sehingga mengurangi waktu untuk keluarga. Mereka akan aktif jika terhubung dengan jaringan wifi publik terutama pada saat berada di kantor. Distribusi penyuluh berdasarkan biaya pengeluaran akses dapat dilihat dalam Tabel 6 .

Sebagian besar penyuluh menggunakan paket wifi rumah, namun sebagian lainnya tidak menggunakan paket wifi rumah (mengandalkan paket data telpon). Penyuluh yang tidak berlangganan wifi rumah karena tinggal di perantauan. Penyuluh yang mengeluarkan biaya rata-rata <Rp.200.000 untuk membeli paket wifi karena mengejar promo dari provider. Jika sinyal jaringan wifi-nya sering mengalami gangguan ditambah promo kompetitor lebih menarik, maka mereka akan cepat berganti ke provider lain. Penyuluh yang membayar harga berlangganan $>$ Rp.301.000 adalah pelanggan setia merk provider tertentu (atau belum ada provider kompetitor di daerah tersebut) dan memiliki mobilitas penggunaan data yang besar. Menurut mereka dengan berlangganan wifi rumah bisa menunjang pekerjaan mereka pada saat work from home dan sebagai sarana hiburan.

Tabel 5. Distribusi Penyuluh Narkoba Berdasarkan Biaya Pengeluaran Akses

\begin{tabular}{clcc}
\hline Sub Variabel & \multicolumn{1}{c}{ Kategori } & N (Orang) & Persentase (\%) \\
\hline Paket Data Ponsel & Tidak ada & 6 & 3,53 \\
& < Rp. 100.000 & 52 & 30,59 \\
& Rp. $101.000-$ Rp.200.0000 & 84 & 49,41 \\
& > Rp. 201.000 & 28 & 16,47 \\
\hline Paket Wifi Rumah & Tidak ada & 93 & 44,08 \\
& <Rp.200.000 & 12 & 5,69 \\
& Rp. 201.000- Rp. 300.000 & 62 & 29,38 \\
& >Rp.301.000 & 44 & 20,85 \\
\hline
\end{tabular}

Hasil wawancara dengan beberapa orang penyuluh menyebutkan, penyebab rendahnya pemanfaatan media digital dalam penyuluhan karena masih banyak penyuluh yang melakukan kegiatan penyuluhan offline seperti penyuluhan tatap muka ataupun menggunakan mobil sosialisasi keliling. Penggunaan mobil sosialisasi keliling masih banyak digunakan pada massa Pandemi dengan konsep singgah sebentar (on the spot) di titik keramaian masyarakat dengan tujuan sebagai upaya pelayanan penyuluh untuk tetap hadir di tengah masyarakat. Kegiatan ini bertujuan untuk (1) memberikan informasi dan 
edukasi tentang bahaya dan dampak penyalahgunaan narkoba, (2) membantu pemerintah dalam upaya memutus penyebaran mata rantai Virus Covid-19, dan (3) menghimbau kepada masyarakat agar mematuhi Protokol Kesehatan di Era New Normal.

\section{Karakteristik Inovasi}

Karakteristik inovasi dapat membantu mengurangi ketidakpastian tentang inovasi sehingga memengaruhi tingkat kecepatan relatif sebuah inovasi oleh penyuluh terkait pemanfaatan media digital. Karakteristik inovasi pemanfaatan media digital oleh penyuluh adalah proses penyuluh menyaring, memilih, mengatur, dan menafsirkan rangsangan untuk memberi makna tentang inovasi yang di ukur melalui keuntungan relatif, kompatibilitas, kompleksitas, trialbilitas, dan observabilitas. Rataan distribusi penyuluh berdasarkan karakteristik inovasi berada dalam kategori sedang (rataan 61,77), secara terperinci dapat dilihat dalam Tabel 6.

Tabel 6. Distribusi Penyuluh Narkoba berdasarkan Karakteristik Inovasi dan Kategorinya

\begin{tabular}{lcc}
\hline \multicolumn{1}{c}{ Sub Variabel } & Rataan & Kategori \\
\hline Keuntungan relatif & 58,73 & Sedang \\
Kompatibilitas & 64,31 & Sedang \\
Kompleksitas & 60,15 & Sedang \\
Trialbilitas & 63,28 & Sedang \\
Observabilitas & 62,40 & Sedang \\
\hline Rataan Peubah & 61,77 & Sedang \\
\hline
\end{tabular}

Keuntungan relatif adalah tingkatan suatu inovasi dianggap lebih baik atau menguntungkan (secara ekonomis) daripada yang ada sebelumnya. Apabila inovasi baru dianggap memiliki keuntungan relatif besar dari nilai yang dihasilkan oleh teknologi lama, maka kecepatan proses adopsi inovasi akan berjalan lebih cepat (Budiman et al. 2020). Rataan keuntungan relatif adopsi inovasi penyuluh berada dalam kategori sedang. Hasil ini menunjukkan bahwa sebagian besar penyuluh meyakini bahwa keuntungan relatif dari pemanfaatan media digital secara ekonomis maupun aspek sosial lebih baik jika dibandingkan dengan metode penyuluhan konvensional tatap muka. Perbandingan keuntungan relatif pemanfaatan media digital dapat dilihat dalam Tabel 7.

Tabel 7. Perbandingan Aspek Keuntungan Relatif

\begin{tabular}{lll}
\hline \multicolumn{1}{c}{ Aspek Keuntungan Relatif } & \multicolumn{1}{c}{ Penyuluhan Daring } & \multicolumn{1}{c}{ Penyuluhan Luring } \\
\hline $\begin{array}{l}\text { Jumlah penyuluhan dalam satu } \\
\text { bulan }\end{array}$ & $\begin{array}{l}\text { lebih banyak dan beragam, } \\
\text { termasuk produktivitas konten } \\
\text { digital }\end{array}$ & $\begin{array}{l}\text { hanya 1-2 kali penyuluhan } \\
\text { yang dapat dilakukan }\end{array}$ \\
Ketertarikan khalayak & $\begin{array}{l}\text { lebih tertarik karena konten } \\
\text { yang disajikan tidak monoton }\end{array}$ & $\begin{array}{l}\text { kurang tertarik karena } \\
\text { berbentuk ceramah (monoton) }\end{array}$ \\
$\begin{array}{l}\text { Kecepatan menyebarkan } \\
\text { informasi }\end{array}$ & $\begin{array}{l}\text { lebih cepat karena tidak ada } \\
\text { batasan jangkauan penerima } \\
\text { pesan }\end{array}$ & $\begin{array}{l}\text { lebih lambat karena } \\
\text { keterbatasan jangkauan } \\
\text { penerima yang ada di lokasi } \\
\text { penyuluhan } \\
\text { Biaya Produksi }\end{array}$ \\
& $\begin{array}{l}\text { lebih murah karena } \\
\text { mengandalkan jaringan internet }\end{array}$ & $\begin{array}{l}\text { tergantung jenis media } \\
\text { penyiaran dan waktu tayang }\end{array}$ \\
\hline
\end{tabular}

Karakteristik inovasi kompatibilitas adalah inovasi yang tidak sesuai dengan ciri-ciri sistem sosial (pengalaman, nilai, dan kebutuhan) yang menonjol tidak akan diadopsi secepat dengan yang kompatibel. Media digital dianggap cukup kompatibel dan sesuai dengan kebutuhan penyampaian pesan informasi kepada khalayak (rataan sedang) di masa pandemi. Penyuluh menganggap media Online/Internet dapat mendukung tugas penyuluh yaitu mencari informasi untuk bahan konten penyuluhan. Kegiatan saling mencari dan menyebarkan informasi dan data terkini banyak dilakukan oleh penyuluh melalui grup-grup WhatsApp internal yang diikuti oleh para penyuluh narkoba. Media digital seharusnya dapat mempermudah penyuluh dalam melakukan penyuluhan dilihat dari sisi 
kemudahan penggunaan. Dengan fitur modern yang ada, penyuluh cocok menggunakan media online untuk penyuluhan.

Pengenalan media digital terutama webinar dan pembuatan flyer diawal masa pandemi menyebabkan beberapa penyuluh tua perlu diberikan bimbingan khusus dari penyuluh muda. Fakta ini sejalan dengan temuan penelitian Helmy et al., (2013) yang menemukan fakta bahwa penyuluh tua cenderung mengalami kesulitan untuk memanfaatkan media digital. Penyuluh juga merasa kepercayaan diri lebih besar ketika melakukan presentasi (public speaking) secara daring jika dibandingkan dengan penyuluhan tatap muka secara langsung.

Kompleksitas adalah tingkat suatu inovasi dianggap relatif sulit untuk dimengerti dan digunakan. Inovasi tertentu begitu mudah dapat dipahami oleh penerima tertentu namun tidak bagi sebagian yang lain. Keberhasilan suatu inovasi sangat ditentukan oleh tingkat kerumitan adopsinya. Tabel 7 membuktikan bahwa penerapan inovasi dianggap oleh sebagian penyuluh adalah cukup rumit dengan rataan skor 60,14. Menurut penyuluh, media digital yang digunakan untuk penyuluhan agak rumit karena penyuluh harus mengetahui karakteristik masing-masing media digital yang ada. Bagi para penyuluh kategori muda dan dewasa sangat cepat untuk mengadopsi media digital dalam kegiatan penyuluhan sehari-hari. Bagi para senior mereka sempat mengalami kegagapan teknologi untuk mengadopsi inovasi baru. Para penyuluh tua ini kadangkala menurut para yuniornya di kantor terkesan menyembunyikan ketidakmampuan mereka dalam mengoperasikan perangkat digital.

Munculnya kewajiban melaksanakan penyuluhan digital membuat para senior penyuluh mengejar ketertinggalan dengan belajar kepada penyuluh lebih muda yang memahami pengoperasian aplikasi digital. Sebaliknya para penyuluh muda terus membimbing para seniornya agar mahir dalam mengoperasikan perangkat digital. Secara kualitas konten yang dihasilkan masih dalam tahap belajar dan terkesan sekedar menggugurkan kewajiban akan produksi konten dalam bentuk flyer.

Fakta berbeda terlihat ketika konten yang diproduksi adalah kegiatan tim seperti pelaksanaan webinar ataupun pembuatan video. Konten yang dihasilkan akan tampak bagus, meskipun dalam kegiatan tersebut peran para penyuluh tua jarang terlibat urusan teknis. Hasilnya jika kegiatan kolaborasi, maka kelemahan para penyuluh tua terkait pemanfaatan media digital akan tertutupi. Peran seluruh penyuluh di dalam mencari dan menyebarkan informasi dengan media online nampak menonjol. Hampir setiap hari masing-masing akun media sosial yang dimiliki oleh BNN Provinsi dan BNN Kabupaten/Kota.

Observabilitas atau dapat diamati adalah tingkat hasil inovasi yang dapat dilihat, bersifat positif, dan mudah dikomunikasikan oleh orang lain. Hasil penelitian menunjukkan mayoritas penyuluh menyatakan cukup banyak contoh pemanfaatan media digital untuk penyuluhan yang dapat diamati (rataan sedang). Sifat inovasi observabilitas ditunjukkan dari kemudahan penyuluh dalam melihat efek dari pemanfaatan media digital. Penyuluh mengakui dari hasil pengamatan dalam produktivitas pembuatan dan penyebaran konten cukup merata di seluruh BNN. Hal ini karena pimpinan di setiap satuan kerja BNN menginstruksikan agar setiap hari ada konten yang dihasilkan dan di unggah di akun resmi milik kantor. Tim humas di beberapa satuan kerja membuat konten resmi sebagai representasi dari kantor. Satuan kerja yang belum terlihat peran humasnya, para penyuluh berinisiatif untuk membuat jadwal unggahan konten diantara mereka.

Trialabilitas adalah tingkat kemudahan suatu inovasi dapat dicoba dengan skala kecil. Kemudahan inovasi untuk dapat dicoba oleh pengadopsi berkaitan dengan keterbatasan sumber daya yang dimiliki. Sebuah inovasi semakin mudah dapat dicoba maka relatif cepat proses adopsi inovasi yang dilakukan oleh penyuluh. Hasil penelitian menunjukkan tingkat uji coba pemanfaatan media digital untuk mendukung kompetensi penyuluh adalah cukup dapat diujicoba (rataan 63,28). Uji coba pemanfaatan media digital dilakukan oleh penyuluh dilakukan dengan pembuatan dan penyebaran konten digital melalui berbagai macam aplikasi. Proses adaptasi dan pembelajaran secara offline maupun online tidak berlangsung lama dan dilakukan melalui grup WhatsApp. Penyuluh juga merasa tidak kesulitan memilih media online yang digunakan untuk penyuluhan. Pelaksanaan webinar ini mayoritas penyuluh menggunakan aplikasi Zoom dibanding dengan google meet, ataupun skype yang sudah banyak ditinggalkan penggunaanya. Secara sederhana pembuatan konten digital adalah membuat poster melalui aplikasi Powerpoint, ataupun aplikasi online seperti Canva, Pictochart, Postermywall, dan lainnya. Pembuatan konten video dilakukan dengan aplikasi KineMaster ataupun Scracth. 


\section{Dukungan Kelembagaan}

Dukungan kelembagaan menurut Mardikanto (2009) adalah dukungan yang diberikan oleh induk organisasi penyuluh (BNN) diantaranya adalah ketersediaan fasilitas yang diberikan kepada penyuluh guna membantu memudahkan penyuluh dalam melaksanakan tugas di lapangan. Penelitian ini akan dilihat seberapa penting dukungan kelembagaan yang mencakup Iklim kerja dan Dukungan kebijakan. Dukungan kelembagaan (Tabel 8) yang diperoleh penyuluh narkoba untuk memanfaatkan media digital berada dalam kategori Sedang (rataan 55,98).

Tabel 8. Dukungan Kelembagaan

\begin{tabular}{lcc}
\hline \multicolumn{1}{c}{ Sub Variabel } & Rataan & Kategori \\
\hline Iklim kerja & 51,62 & Sedang \\
Dukungan atasan & 60,34 & Sedang \\
\hline Rataan Peubah & 55,98 & Sedang \\
\hline
\end{tabular}

Iklim kerja adalah suasana di tempat penyuluh melakukan kegiatan penyuluhan yang mencakup kondisi sosial dan dukungan sarana dan prasarana dari kantor. Menurut Diyanti et al. (2017), iklim kerja organisasi memiliki pengaruh terhadap kepuasan kerja yang pada akhirnya akan berpengaruh juga terhadap kinerja organisasi. Iklim kerja penyuluh berada dalam kategori sedang (Tabel 8), artinya penyuluh merasa cukup terbantu dengan adanya iklim kerja yang kondusif. Iklim kerja dari penelitian ini dapat dilihat dari dukungan administrasi dan Sarana Prasarana TIK.

Hasil wawancara menguatkan adanya dukungan administrasi dari kantor yang sangat membantu penyuluh dalam melaksanakan tugas penyuluhan. Dukungan ini terkait kemudahan mendapatkan administrasi surat perintah untuk menjalankan tugas dan disposisi kegiatan terkait undangan penyuluhan yang diserahkan kepada penyuluh dengan alur administrasi yang berjenjang. Terkait sarana dan prasarana TIK, penyuluh menyebutkan jaringan wifi di kantor relatif stabil untuk mendukung penyuluh dalam melaksanakan penyuluhan online. Untuk komputer dan laptop, penyuluh menyebutkan masih banyak yang belum terfasilitasi karena inventaris kantor berjumlah terbatas. Keterbatasan ini kemudian disiasati dengan membawa sendiri perangkat digital untuk menunjang pekerjaan.

Menurut Firmansyah et al. (2015), dukungan atasan merupakan salah satu bentuk kepuasan sosial yang pada akhirnya dapat memotivasi penyuluh untuk meningkatkan kompetensi. Dukungan atasan yang diterima oleh penyuluh akan berbeda-beda tergantung dari kebijakan masing-masing atasan. Bentuk dukungan Atasan adalah (1) memberikan kesempatan penyuluh untuk melaksanakan penyuluhan, (2) mempersilahkan penyuluh berimprovisasi terkait metode dan teknik penyuluhan, serta (3) membantu penyuluh ketika menghadapi masalah di dalam pekerjaan.

Atasan kadangkala tidak memperkenankan penyuluh memberikan penyuluhan yang berbasiskan anggaran DIPA di beberapa satuan kerja. Sesuai dengan aturan, penyuluh yang menjadi narasumber maka anggaran narasumber bisa diserap, sehingga dikhawatirkan serapan anggaran pada akhir tahun akan rendah. Solusi terbaik untuk mengatasinya adalah penyuluh lebih banyak melakukan penyuluhan yang tidak menggunakan anggaran (Non DIPA). Hasil wawancara dengan beberapa penyuluh diketahui bahwa Kepala satuan kerja BNN yang melakukan pendekatan instruktif akan lebih banyak menghasilkan penyuluhan digital yang dilakukan penyuluh.

Selain itu terkait keterbatasan jumlah personel maka mayoritas penyuluh juga mengerjakan tugastugas adminitrasi perkantoran seperti (1) surat menyurat, (2) kepanitiaan kegiatan, (3) menginput data di aplikasi-aplikasi kinerja, dan (4) pembuatan laporan keuangan kegiatan di luar tugas utamanya sebagai penyuluh narkoba. Fakta ini sejalan dengan temuan penelitian yang disampaikan oleh Bahua dan Marleni (2016) bahwa penyuluh tidak mampu bahkan tidak sempat mengembangkan kemampuan profesional sebagai penyuluh karena banyak kegiatan yang ditetapkan atasan yang kadang-kadang tidak sesuai dengan tugas sebagai penyuluh professional.

\section{Kompetensi Penyuluh}

Kompetensi menurut Baartman dan De Bruijn (2011), Sapar et al. (2012), Bahua dan Marleni (2016), dan Pramono et al., (2017) adalah segala bentuk motif, sikap, keterampilan, perilaku atau karakteristik pribadi yang penting untuk melaksanakan pekerjaan seseorang yang dipengaruhi oleh pengetahuan, 
keterampilan dan sikap. Menurut Peraturan BNN Nomor 2 tahun 2020 tentang Standar Kompetensi Jabatan Fungsional Penyuluh narkoba, kompetensi terdiri dari kompetensi managerial, teknis, dan sosiokultural.

Secara umum hasil penelitian ini menunjukkan kompetensi penyuluh narkoba berada dalam kategori sedang. Temuan penelitian ini membuktikan bahwa mayoritas penyuluh memiliki kecukupan kemampuan menggunakan media digital terkait tugas pokok dan fungsinya dalam memberikan penyuluhan bahaya penyalahgunaan narkoba kepada masyarakat. Hasil penelitian ini berbeda dengan penelitian yang dilakukan oleh Anwas (2011) dan Humaidi et al. (2020) yang menemukan bahwa kompetensi penyuluh berada dalam kategori rendah. Hasil berbeda juga dilakukan oleh Syafruddin et al. (2013) yang menyatakan kompetensi penyuluh berada dalam kategori tinggi.

Pandangan khalayak terhadap kompetensi penyuluh menurut Muslihat et al. (2015) adalah tergantung pada faktor konsumsi media. Semakin banyak konsumsi media yang dilakukan oleh penyuluh maka akan semakin banyak pengetahuan yang akan didapatkan, sehingga kesempatan untuk menjawab pertanyaan yang diajukan masyarakat juga semakin bermutu. Media digital dapat dimanfaatkan penyuluh untuk (1) mencari informasi, (2) menciptakan pesan, (3) memberi komentar, dan (4) menyampaikan pendapat dengan jejaring sosial yang dimiliki secara cepat dan tidak terbatas. Tabel 9 menunjukkan bahwa rataan peubah kompetensi penyuluh narkoba berada dalam kategori sedang. Artinya penyuluh memiliki cukup kompetensi dalam memanfaatkan media digital yang dapat digunakan untuk penyuluhan.

Tabel 9. Kompetensi Penyuluh

\begin{tabular}{lcc}
\hline \multicolumn{1}{c}{ Sub Variabel } & Rataan & Kategori \\
\hline Pengetahuan & 65,49 & Sedang \\
Keterampilan & 62,53 & Sedang \\
Sikap & 59,07 & Sedang \\
\hline Rataan Peubah & 62,36 & Sedang \\
\hline
\end{tabular}

Kompetensi pengetahuan adalah ilmu pengetahuan yang mutlak harus dikuasai agar dapat melaksanakan pekerjaan yang erat hubungannya dengan pekerjaan tetapi tidak langsung digunakan. Kompetensi pengetahuan penyuluh di uji dengan 9 (sembilan) pertanyaan yang terkait pengetahuan tentang webinar dan produktivitas konten digital. Hasilnya kompetensi penyuluh memiliki rataan sedang. Dua orang penyuluh yang memiliki pengetahuan rendah adalah mereka yang belum pernah mengikuti pelatihan sama sekali terkait pencegahan narkoba. Hasil penelitian ini berbeda dengan penelitian Irhandayaningsih (2020) yang menemukan fakta bahwa kemampuan literasi digital yang dimiliki penyuluh (narkoba) berada dalam kategori tinggi.

Kompetensi kemampuan teknis (skill) adalah kemampuan untuk mengerjakan tugas secara fisik dan mental (Bahua, 2016). Keterampilan bidang TIK dilakukan melalui penciptaan dan penyusunan konten digital yang merupakan kompetensi utama dalam bidang literasi digital, dan melibatkan kemampuan merakit informasi atau pengetahuan (Irhandayaningsih, 2020) dalam penyuluhan digital. Ketrampilan dalam memanfaatkan media digital dilihat dari rutinitas penyuluh memanfaatkan teknologi informasi dan komunikasi yang dimiliki dan diakses. Kompetensi ketrampilan penyuluh berada dalam kategori sedang. Hal ini membuktikan bahwa kemampuan penyuluh dalam literasi digital sudah cukup terampil yang ditandai dengan rutinitas pengoperasian perangkat digital yang dimilikinya.

Rutinitas memanfaatkan media digital dilakukan penyuluh diawali dengan berselancar online dengan Chrome, Mozilla, Opera, dll. Penyuluh akan mencari informasi terkait konten yang akan dibuat di internet. Hasil dari pencarian informasi tersebut dituangkan dalam sebuah konsep yang akan didiskusikan dengan penyuluh sejawat, ataupun dengan persetujuan atasan.

Rutinitas selanjutnya terkait kemampuan install dan uninstall aplikasi baik di komputer ataupun di telepon pintar yang dimiliki. Kegunaan install dan uninstall aplikasi adalah untuk meringankan beban perangkat teknologi agar berjalan lebih cepat, mengurangi pemborosan baterai, perangkat tidak cepat panas, dan yang utama adalah berkaitan dengan fungsi aplikasi tersebut apakah masih sesuai dengan kebutuhan penyuluh atau tidak. 
Terkait dengan faktor keamanan dari perangkat digital yang di gunakan, sebagian besar penyuluh menyimpan data sebagai cadangan baik itu di flashdisk, Hardisk eksternal, perangkat lain, ataupun menyimpannya secara online di Google Drive, Cloud, atau Dropbox. Penyimpanan data perangkat digital dilakukan secara berkala. Untuk melindungi data dan akun digital yang digunakan, penyuluh memproteksinya dengan kata kunci. Informasi dan data yang menarik dan terkait konten yang akan dibuat oleh penyuluh akan di unduh, selanjutnya hasil produksi konten akan di unggah dan disebarkan di halaman media digital yang dimiliki. Penyuluh secara berkala rajin memperbarui sistem operasi perangkat digital yang digunakan. Kemampuan teknis yang dimiliki penyuluh ini adalah kemampuan standar minimal yang telah dimiliki oleh para penyuluh, tetapi kemampuan teknis lainnya terkait kualitas konten yang dihasilkan belum terlihat secara umum.

Sikap adalah konsep diri dan nilai-nilai yang dimiliki individu (Anwas et al. 2010). Sikap merupakan perilaku yang terkait dengan tata cara penggunaan informasi digital, dan bagaimana mengkomunikasikan suatu konten yang mengandung informasi dari sumber lain (Irhandayaningsih, 2020). Penyuluh dituntut memiliki kepekaan terhadap setiap perubahan, termasuk perubahan metode penyuluhan yang lebih baik dan efektif efisien. Kompetensi sikap yang dimiliki penyuluh berada dalam kategori Sedang, artinya sikap penyuluh dalam penyuluhan digital adalah cukup baik.

Hasil penelitian menunjukkan, penyuluh merasa memiliki rasa percaya diri ketika melakukan penyuluhan digital yang timbul karena penyuluh tidak berhadapan langsung (face to face) dengan klien. Menurut penyuluh, kreativitas dan kualitas pembuatan konten tidak bisa dipaksakan (tekanan) dan bisa muncul dalam situasi dan kondisi apa saja. Penyuluh juga memiliki rasa tanggung jawab untuk tertib membuat konten dalam kurun waktu tertentu, meskipun kadang ada kecemburuan terkait perbedaan jumlah konten yang dihasilkan penyuluh lain. Terkait dengan difusi inovasi metode penyuluhan, mayoritas penyuluh tidak mengalami kesulitan ketika diharuskan merubah metode penyuluhan konvensional menjadi digital.

\section{Pengaruh Pemanfaatan Media Digital Terhadap Kompetensi}

Pengaruh pemanfaatan media digital terhadap kompetensi penyuluh secara jelas dapat dilihat dari nilai koefisien jalur, t-statistik, dan $R$-Square. Tahap pertama dalam pengujian hipotesis penelitian menggunakan PLS adalah dengan melihat Loading factor untuk menganalisis pengukuran (outer model) menilai validitas dan reliabilitas model. Melalui proses iterasi logaritma, paramater model pengukuran (validitas konvergen, validitas diskriminan, composite reliability dan cronbach's alpha) diperoleh termasuk nilai $R$-Square sebagai parameter ketetapan model prediksi.

Analisis pengukuran (outer model) melalui proses PLS algorithm dilakukan dua kali. Hal tersebut karena ketika pertama kali dilakukan terdapat peubah yang memiliki nilai loading factor di bawah 0,6 (penelitian eskplanatori. Artinya indikator tersebut tidak merefleksikan masing-masing peubah laten (tidak valid dan tidak reliabel). Peubah kompetensi pengetahuan harus di keluarkan karena memiliki nilai loading factor $-0,127$. Artinya, semakin banyak pengetahuan tentang media digital yang dimiliki penyuluh, malah akan semakin enggan untuk menerapkannya dalam penyuluhan digital. Fakta ini menunjukkan bahwa kompetensi pengetahuan yang dimiliki penyuluh narkoba tidak digunakan maksimal untuk penyuluhan digital. Setelah dilakukan analisis ulang, seluruh peubah memiliki nilai loading factor antara 0,609-0,881.

Tabel 10 menunjukkan nilai AVE setiap peubah berada diantara 0,51-0,593 sehingga bisa dikatakan valid. Penggunaan Cronbach's Alpha (CA) akan memberi nilai yang lebih rendah (under estimate) sehingga lebih disarankan menggunakan CR untuk menilai reliabilitas konstruk (Ghozali \& Latan, 2019). Menurut kaidah umum nilai CR harus $\geq 0,7$. Merujuk Tabel 10, dapat dilihat nilai CR dari masing-masing peubah berada diantara $0,732-0,838$. Jadi persamaan model struktural dalam penelitian pengaruh pemanfaatan media digital dalam menunjang kompetensi, yaitu:

$$
\mathrm{Y}_{1}=-0,162 \mathrm{X}_{1}+0,226 \mathrm{X}_{2}+0,308 \mathrm{X}_{3}+0,184 \mathrm{X}_{4}+0,742 \text {. }
$$


Model struktural (inner model) disajikan pada Tabel 10.

Tabel 10. Uji Validitas \& Reliabilitas

\begin{tabular}{lcccc}
\hline Uji Validitas \& Reliabilitas & Cronbach's Alpha & rho_A & Composite Reliability & AVE \\
\hline Dukungan Kelembagaan & 0,333 & 0,377 & 0,74 & 0,593 \\
Karakteristik Individu & 0,64 & 0,621 & 0,804 & 0,579 \\
Karakteristik Inovasi & 0,766 & 0,781 & 0,838 & 0,51 \\
Kompetensi Penyuluh & 0,273 & 0,277 & 0,732 & 0,578 \\
\hline
\end{tabular}

Tahap kedua yaitu analisis struktural (inner model) digunakan untuk mengetahui hubungan antar peubah laten dengan peubah laten yang lain, baik eksogen maupun endogen, dan juga dapat digunakan sebagai pengujian hipotesis. Melalui proses bootstraping, parameter uji T-statistic diperoleh untuk memprediksi adanya hubungan kausalitas (Jogiyanto, 2011). Penilaian model struktural (inner model) digunakan nilai $R$-Square untuk mengukur tingkat variasi perubahan variabel independen terhadap variabel dependen dan Signifikansi (Hamid dan Anwar, 2019). Signifikansi hubungan antar konstrak dapat dilihat dari koefisien jalur yang dapat memberi gambaran mengenai kekuatan hubungan antar konstrak, hasilnya dapat dilihat pada Gambar 3.

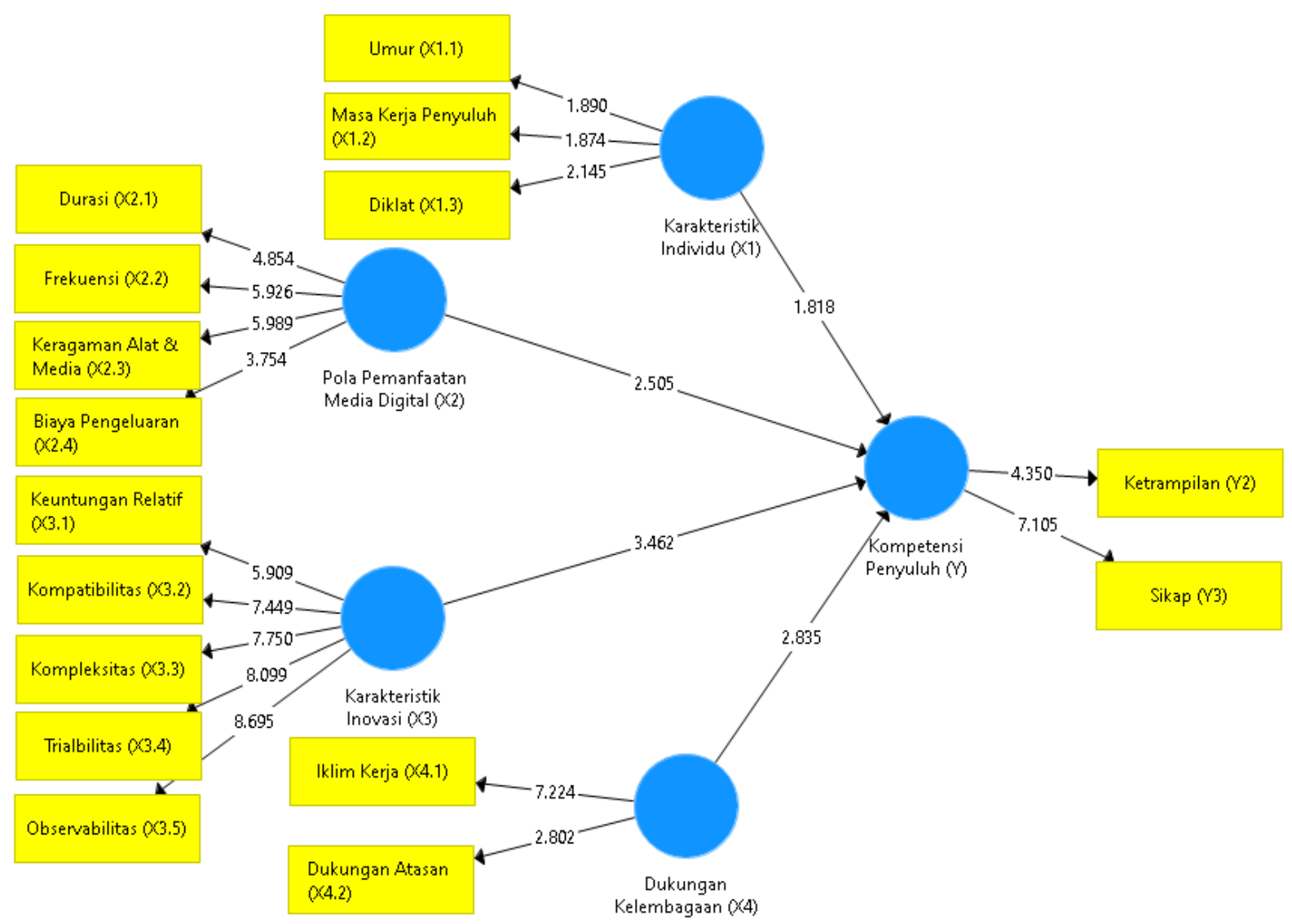

Gambar 3. Model analisis PLS koefisiensi jalur

Gambar 3 dapat mengindikasikan bahwa semua konstruk bernilai positif. Hal ini menunjukkan jika semakin besar nilai koefisiensi jalur pada variabel independen terhadap variabel dependen maka semakin kuat pengaruh antar variabel independen terhadap variabel dependen. Pengaruh yang paling kuat ada pada variabel karakteristik inovasi $(3,462)$. Hal ini membuktikan kompetensi penyuluh terkait proses adopsi inovasi metode penyuluhan digital akan meningkat jika persepsi penyuluh narkoba terkait karakteristik inovasi juga meningkat. Sedangkan variabel yang memiliki pengaruh paling kecil adalah variabel karakteristik individu $(1,818)$. Hal ini membuktikan tidak cukup bukti bahwa 
karakteristik Individu yang dimiliki oleh penyuluh seperti umur dan masa kerja sebagai penyuluh berpengaruh terhadap kompetensi penyuluh narkoba.

Selanjutnya kriteria penilaian model struktural (inner model) yang kedua adalah signifikansi. Peubah laten independen dinyatakan signifikan memengaruhi peubah laten dependen jika memiliki nilai $t$ statistik > t Tabel $(1,96)$ dengan signifikansi 5\%. Hasil pengujian signifikansi peubah secara jelas dapat dilihat pada Tabel 11.

Tabel 51. Nilai signifikansi Peubah Laten

\begin{tabular}{lccc}
\hline \multicolumn{1}{c}{ Pengaruh Antar Peubah } & Original Sample (O) & T Statistics & P Values \\
\hline $\begin{array}{l}\text { Dukungan Kelembagaan -> Kompetensi } \\
\text { Penyuluh }\end{array}$ & 0,184 & 2.707 & 0,007 \\
$\begin{array}{l}\text { Karakteristik Individu -> Kompetensi } \\
\begin{array}{l}\text { Penyuluh } \\
\text { Karakteristik Inovasi -> Kompetensi }\end{array}\end{array}$ & $-0,162$ & 1.944 & 0,052 \\
$\begin{array}{l}\text { Penyuluh } \\
\begin{array}{l}\text { Pola Pemanfaatan Media Digital -> } \\
\text { Kompetensi Penyuluh }\end{array}\end{array}$ & 0,308 & 3.402 & 0,001 \\
\hline
\end{tabular}

Hanya variabel karakteristik individu yang memiliki pengaruh negatif dan tidak berpengaruh nyata terhadap kompetensi penyuluh narkoba dari semua variabel independen dalam penelitian ini. Faktor yang merefleksikan karakteristik individu dan signifikan terhadap kompetensi penyuluh adalah jumlah diklat yang pernah diikuti dengan koefisien 2,151. Faktor umur dan masa kerja sebagai penyuluh tidak berpengaruh signifikan karena memiliki nilai koefisien yang lebih rendah dari T-tabel.

Hasil ini membuktikan, untuk meningkatkan kompetensi penyuluh adalah dengan mengikutsertakan penyuluh di dalam diklat dasar fungsional, diklat penjenjangan, dan diklat teknis fungsional yang berhubungan dengan standar kompetensi penyuluh. Semakin banyak penyuluh mengikuti diklat maka kompetensinya akan semakin meningkat. Sebaliknya jika semakin sedikit penyuluh mengikuti diklat maka kompetensinya akan mengalami stagnansi. Data di lapangan menunjukkan, penyuluh angkatan 2015, 2018, dan hasil redistribusi 2017 belum mengikuti diklat dasar fungsional penyuluh narkoba (95 orang). Hasil penelitian ini berbeda dengan temuan penelitian yang dilakukan oleh Helmy et al., (2013), yang menemukan bahwa faktor karakteristik individu penyuluh berhubungan secara nyata dengan kompetensi penyuluh.

Faktor yang merefleksikan pola pemanfaatan media digital dan signifikan terhadap kompetensi penyuluh narkoba adalah durasi, frekuensi, keragaman alat dan media yang digunakan, serta biaya pengeluaran untuk akses (Gambar 3). Nilai koefisien paling besar di antara keempat indikator tersebut adalah Keragaman Alat dan media digital $(5,988)$. Artinya semakin banyak dan beragam alat serta media digital yang digunakan oleh penyuluh narkoba maka akan semakin meningkatkan kompetensi yang dimilikinya.

Keragaman alat dan media digital masih bisa ditingkatkan dengan meningkatkan pola akses internet dengan menambah jumlah alat dan media. Penyuluh narkoba juga harus beradaptasi dengan kemajuan teknologi komunikasi yang salah satunya adalah dengan memiliki dan mengoperasionalkan secara rutin akun-akun media digital. Semakin banyak akun media digital yang dimiliki dan dioperasionalkan secara rutin maka akan semakin meningkat kompetensi yang akan dimilikinya.

Keberadaan akun media digital tersebut dapat membantu memperluas sebaran informasi kepada khalayak. Penyuluh juga bisa menggunakannya untuk memperbanyak webinar-webinar yang dapat diselenggarakan secara individu ataupun kolaborasi antar sesama penyuluh dari wilayah kerja yang berbeda agar menambah minat khalayak untuk mengikutinya. Selain itu penyuluh juga diharapkan dapat memaksimalkan fungsi media digital sebagai media pembelajaran, bukan hanya sebatas mengunggah konten yang telah diproduksi. Hasil pengamatan di lapangan membuktikan penyuluh belum optimal dalam mengelola dan menanggapi umpan balik dari klien yang berupa like dan comment.

Faktor karakteristik inovasi memiliki pengaruh paling besar dan signifikan terhadap kompetensi penyuluh dalam memanfaatkan media digital untuk penyuluhan. Secara berurutan faktor tersebut adalah; observabilitas, trialbilitas, kompleksitas, kompatibilitas, dan keuntungan relatif. Hal ini 
membuktikan, semakin tinggi nilai koefisiensi maka akan semakin besar pengaruh karakteristik inovasi terhadap peningkatan kompetensi penyuluh narkoba.

Besarnya nilai koefisiensi observabilitas penyuluh dalam difusi inovasi pemanfaatan media digital adalah karena penyuluh dengan mudah dapat mengamati secara langsung pemanfaatan media digital untuk penyuluhan baik secara daring maupun secara luring. Pengamatan secara daring dapat dilihat dari adanya informasi dan sharing konten digital yang disebar melalui grup-grup WhatsApp yang setiap saat dilakukan oleh penyuluh seluruh Indonesia. Pengamatan secara luring dilakukan di internal satuan kerja penyuluh dengan melihat teman sesama penyuluh yang membuat konten digital. Hasil dari pengamatan ini akhirnya memotivasi penyuluh untuk mempercepat proses adopsi inovasi pada dirinya yang pada akhirnya dapat meningkatkan kompetensi penyuluh karena ia akan melakukan percobaan sendiri.

Berdasarkan Gambar 3 faktor yang merefleksikan dukungan lembaga dan signifikan memengaruhi kompetensi penyuluh adalah iklim kerja dan dukungan atasan. Iklim kerja berpengaruh secara signifikan koefisiensinya karena mayoritas penyuluh menyatakan iklim kerja yang positif dan kondusif akan meningkatkan semangat penyuluh dalam pembuatan konten digital. Faktor dukungan atasan meskipun berpengaruh, namun masih bisa ditingkatkan dengan memberikan pembinaan koersif kepada penyuluh secara rutin untuk meningkatkan pemanfaatan media digital. Hasil penelitian membuktikan, Kepala satuan kerja BNN yang melakukan pembinaan koersif baik secara lesan maupun tertulis akan meningkatkan produktivitas konten yang dihasilkan oleh penyuluh.

Nilai $R$-Square dalam penelitian ini sebesar 0,258 menunjukkan bahwa 25,8\% kompetensi penyuluh narkoba dipengaruhi oleh faktor-faktor yang diteliti dalam penelitian, sedangkan $74,2 \%$ dipengaruhi oleh faktor lain di luar penelitian ini. Berdasarkan nilai $R$-Square maka model yang dihasilkan termasuk kategori lemah (di bawah 0,5). Tabel 11 menunjukkan bahwa nilai t-statistik dari peubah karakteristik inovasi, Dukungan Kelembagaan, dan Pola Pemanfaatan Media Digital dari t-Tabel $(1,96)$ dengan nilai $\mathrm{p}$-value $\leq 0,01$. Artinya tingkat kompetensi penyuluh dalam pemanfaatan media digital dipengaruhi secara nyata oleh karakteristik inovasi, dukungan kelembagaan, dan pola pemanfaatan media digital. Artinya, kompetensi penyuluhan digital penyuluh akan meningkat jika terdapat peningkatan pola pemanfaatan media digital yang dilakukan oleh penyuluh, karakteristik inovasi, dan dukungan kelembagaan. Hasil penelitian ini berbeda dengan penelitian yang dilakukan oleh E. O. M. Anwas et al., (2010) yang menemukan bahwa pemanfaatan internet tidak berpengaruh nyata terhadap peningkatan kompetensi penyuluh.

\section{KESIMPULAN}

Kesimpulan yang dapat diambil dari penelitian ini adalah karakteristik penyuluh sebagian besar berusia muda (24-35 tahun), memiliki masa kerja sebagai penyuluh 1-7 tahun, dan masih kurang mendapatkan kesempatan mengikuti diklat pengembangan diri. Penyuluh memiliki kecukupan dalam memanfaatkan media digital untuk penyuluhan. Instagram adalah jenis media digital yang paling banyak digunakan untuk penyuluhan digital. WhatsApp adalah media digital yang dimiliki oleh seluruh penyuluh namun kurang dimanfaatkan untuk penyuluhan dan hanya untuk komunikasi. Penyuluh cukup mudah untuk menerima dan mengaplikasikan inovasi baru terkait pemanfaatan media digital yang digunakan untuk penyuluhan. Penyuluh dalam bekerja mendapat cukup dukungan dari lingkungan kerjanya. Besarnya dukungan kelembagaan dari penyuluh menyebabkan kondusifitas penyuluh dalam bekerja. Penyuluh memiliki kecukupan kemampuan terkait tugas pokok dan fungsinya dalam memberikan penyuluhan bahaya penyalahgunaan narkoba kepada masyarakat. Kompetensi penyuluh dan dipengaruhi faktor pola pemanfaatan media digital, karakteristik inovasi, dan dukungan kelembagaan. Tidak ada pengaruh signifikan faktor karakteristik individu penyuluh yang terdiri dari umur, masa kerja sebagai penyuluh, dan jumlah diklat yang pernah diikuti terhadap kompetensi penyuluh.

\section{DAFTAR PUSTAKA}

[BNN] Pusat Penelitian Data dan Informasi Badan Narkotika Nasional. (2020). Survei Prevalensi Pengalahgunaan Narkoba Tahun 2019. Pusli.

[BNN] Pusat Penelitian Data dan Informasi Badan Narkotika Nasional. (2021). Survei Prevalensi Penyalahgunaan Narkoba 2020 (1st ed.). Puslitdatin BNN. https://ppid.bnn.go.id/konten/unggahan/2020/10/7.Survei-Prevalensi-Penyalahgunaan-Narkoba- 
Kuantitatif-2019.pdf

Ahuja, V. (2011). Cyber Extension: a Convergence of Ict and Agricultural Development. Global Media Journal, 2(2), 1-8.

Akpotosu, B. W., Annor-Frempong, F., \& Bosompem, M. (2017). Determinants of agricultural extension agents' internet competencies in Eastern Region of Ghana. International Journal of Research Studies in Computing, 6(1), 1-7. https://doi.org/10.5861/ijrsc.2017.1758

Anwas, E. O. M., Sumardjo, Asngari, P. S., \& Tjitropranoto, P. (2010). Model Pengembangan Kompetensi Penyuluh Berbasis Pemanfaatan Media (Kasus Di Kabupaten Karawang dan Garut, Provinsi Jawa Barat). Jurnal Penyuluhan, 6, 1-10. https://doi.org/https://doi.org/10.25015/penyuluhan.v6i1.10660

Anwas, O. M. (2011). Kompetensi Penyuluh Pertanian dalam Memberdayakan Petani. Jurnal Matematika, Saint Dan Teknologi, 12(1), 46-55. http://jurnal.ut.ac.id/index.php/JMST/articel/download

Baartman, L. K. J., \& De Bruijn, E. (2011). Integrating knowledge, skills and attitudes: Conceptualising learning processes towards vocational competence. Educational Research Review, 6(2), 125-134. https://doi.org/10.1016/j.edurev.2011.03.001

Bahua, Mohamad Ikbal. (2018). Peran Kompetensi Penyuluh Pertanian pada Keterampilan Petani Bawang Merah. Agriekonomika, 7(2), 112-119. https://doi.org/10.21107/agriekonomika.v7i2.4489

Bahua, Mohammad Ikbal. (2016). Kinerja Penyuluh Pertanian (1st ed.). Deepublish.

Bahua, Mohammad Ikmal, \& Marleni, L. (2016). Model Pengembangan Kompetensi Penyuluh $\begin{array}{lllll}\text { Pertanian Di Provinsi } & \text { Gorontalo. }\end{array}$ https://doi.org/https://jurnal.unej.ac.id/index.php/JSEP/article/view/5768

Baig, M., \& Aldosari, F. (2013). Agricultural extension in Asia: Constraints and options for improvement. Journal of Animal and Plant Sciences, 23(2), 619-632.

Budiman, A. W., Cahyadi, M., \& Rusdiyana, E. (2020). Adopsi Inovasi Digester Biogas Skala Rumah Tangga Pada Kelompok Tani Suka Maju. American Ethnologist, 47(2), 209. https://doi.org/10.1111/amet.12914

Castells, M. (2009). Communications Power (1st ed.). Oxford University Press Inc.

Diyanti, D., Hubeis, M., \& Affandi, M. J. (2017). Pengaruh Motivasi Kerja dan Iklim Kerja Terhadap Kepuasan Kerja dan Implikasinya Terhadap Kinerja Tenaga Kependidikan Institut Pertanian Bogor. Jurnal Aplikasi Bisnis Dan Manajemen, 3(3), 361-372. https://doi.org/10.17358/jabm.3.3.361

Elian, N., Lubis, D. P., \& Rangkuti, P. A. (2014). Penggunaan Internet dan Pemanfaatan Informasi Pertanian oleh Penyuluh Pertanian di Kabupaten Bogor Wilayah Barat. Jurnal Komunikasi Pembangunan, 12(2), 104-109. https://doi.org/10.29244/jurnalkmp.12.2.\%p

Elian, N., Lubis, D. P., Rangkuti, P. A., Dosen, A., \& Jambi, U. (2014). Penggunaan Internet dan Pemanfaatan Informasi. Jurnal Komunikasi Pembangunan Juli, 12(2), 104-109.

Euriga, E., Amanah, S., Fatchiya, A., \& Asngari, P. S. (2018). Jurnal Penyuluhan, September 2018 Vol. 14 No. 2 Implementasi Penyuluhan Hortikultura Berkelanjutan di Provinsi D.I. Yogyakarta. 14(2), 289-307. https://doi.org/https://doi.org/10.25015/penyuluhan.v14i2.19555

Fatchiya, A. (2010). Tingkat Kapasitas Pembudidaya Ikan dalam Mengelola Usaha Akuakultur secara $\begin{array}{llllll}\text { Berkelanjutan. Jurnal Penyuluhan, } & 6 & \text { No. } & 1(9), & 10 .\end{array}$ https://doi.org/https://doi.org/10.25015/penyuluhan.v6i1.10667

Figna, L. N., Amanah, S., \& Fatchiya, A. (2019). Pengaruh Faktor Internal Penyuluh Terhadap Kompetensi Penyuluh Dalam Diklat Dasar Fungsional di BPP Lembang Lucy. JEPA-Jurnal $\begin{array}{llll}\text { Ekonomi Pertanian Aan } & \text { 3(April). }\end{array}$ https://doi.org/https://doi.org/10.21776/ub.jepa.2019.003.03.19

Firmansyah, Amanah, S., \& Sadono, D. (2015). Motivasi, Kepuasan Kerja, dan Kinerja Penyuluh 
Kehutanan di Kabupaten Cianjur Jawa Barat. Jurnal Penyuluhan, 11(1), 11-22. https://doi.org/https://doi.org/10.25015/penyuluhan.v11i1.9928

Ghimire, R. P. (2016). Assessment of Core Competencies of. Michigan State University.

Ghozali, I., \& Latan, H. (2019). Partial Least Squares ; Konsep , Teknik, dan Aplikasi Menggunakan SmartPLS 3.0 Untuk Penelitian Empiris (2nd ed.). Badan Penerbit Undip.

Groshek, J., \& Groshek, M. C. (2013). Agenda trending: Reciprocity and the predictive capacity of social networking sites in intermedia agenda setting across topics over time. Media and Communication, 1(1), 15-27. https://doi.org/10.12924/mac2013.01010015

Hamid, R. S., \& Anwar, S. M. (2019). Structural Equation Modeling (SEM) Berbasis Varian: Konsep Dasar dan Aplikasi dengan Program SmartPLS 3.2.8 dalam Riset Bisnis (Abiratno, S. Nurdiyanti, \& A. D. Raksanagara (eds.)). PT Inkubator Penulis Indonesia.

Helmy, Z., Sumardjo, Purnaningsih, N., \& Tjitropranoto, P. (2013). Hubungan Kompetensi Penyuluh dengan Karakteristik Pribadi, Persepsi Penyuluh Terhadap Dukungan Kelembagaan dan Persepsi Penyuluh Terhadap Sifat Inovasi Cyber Extensión. Jurnal Agro Ekonomi, 31(1), 1-18. https://doi.org/http://dx.doi.org/10.21082/jae.v31n1.2013.1-18

Hubeis, A. V. S. (2007). Motivasi, Kepuasan Kerja Dan Produktivitas Penyuluh Pertanian Lapangan: Kasus Kabupaten Sukabumi. Jurnal Penyuluhan, 3(2). https://doi.org/10.25015/penyuluhan.v3i2.2156

Humaidi, L., Hubeis, A. V. S., Puspitawati, H., \& Anwas, E. O. M. (2020). Pengaruh Dukungan Lembaga Dan Pemanfaatan Media Sosial Terhadap Peningkatan Kompetensi Penyuluh Pertanian Di Provinsi Kepulauan Riau. Jurnal Pengkajian Dan Pengembangan Teknologi Pertanian, 23(1), 27-51. https://doi.org/10.21082/jpptp.v23n1.2020.p27-51

Irhandayaningsih, A. (2020). Pengukuran Literasi Digital Pada Peserta Pembelajaran Daring di Masa Pandemi COVID-19. Anuva, 4(2), 231-240.

Jogiyanto. (2011). Konsep dan Aplikasi Structural Equation Modeling: Berbasis Varian Dalam Penelitian Bisnis. UPP STIM YKPN.

Kenneth, A. I., Okoedo-okojie, D. U., \& Igbinosa, F. O. (2019). Competence And Internet Usage Among Agricultural Extension Workers In Delta And Edo States, Nigeria. 19(4), 133-140.

Kurniawan, R. (2016). Rancang Bangun Media Center Menggunakan Osmc (Open Source Media Center) Berbasis Raspberry Pi Di Perumahan Griya Pasar Ikan Ii Kota Lubuklinggau. Jurnal Teknologi Informasi Mura, 8(1), 8-16. https://doi.org/10.32767/JTI.V8I1.182

Kustiari, T., Sumardjo, S., Slamet, M., \& Tjitropranoto, P. (2017). Pengaruh Efektivitas Penyuluhan Terhadap Kompetensi Pembudidaya Rumput Laut Polikultur Di Perairan Pantai Utara Pulau Jawa. Jurnal Sosial Ekonomi Kelautan Dan Perikanan, 7(1), 79. https://doi.org/10.15578/jsekp.v7i1.5738

Mulyandari, R. S. H., Sumardjo, Lubis, D. P., \& Panjaitan, N. K. (2010). Implementasi Cyber Extension Dalam Komunikasi Inovasi. Informatika Pertanian, 19(2), 17-43.

Muslihat, E. J., Azhar, Kusmiyati, \& Indriatmi, W. (2015). Kompetensi Penyuluh Pertanian dalam Penyusunan Rancangan Usaha Agribisnis Padi pada BKP5K Kabupaten Bogor Provinsi Jawa Barat. Agriekonomika, 4 Nomor 2, 134-155. https://doi.org/10.1055/s-0032-1329178

Ngomane, T. (2010). From a deficit-based to an appreciative inquiry approach in extension programs: Constructing a case for a positive shift in the current extension intervention paradigm. Journal of International Agricultural and Extension Education, 17(3), 57-68. https://doi.org/10.5191/jiaee.2010.17305

Peraturan Kepala BNN RI Nomor 2 Tahun 2020 Tentang Standar Kompetensi Jabatan Fungsional Penyuluh Narkoba, (2020).

Peraturan Menteri Pemberdayaan Aparatur Negara dan Reformasi Birokrasi Nomor 46 tahun 2014 tentang Penyuluh Narkoba, Pub. L. No. 46 (2014). https://simpeg.bnn.go.id/_uploads/doc_public/201602171921481455711708501.pdf 
Peraturan Pemerintah Republik Indonesia Nomor 11 Tahun 2017 Tentang Manajemen Pegawai Negeri Sipil, (2017).

Prabowo, M., \& Irwansyah, I. (2018). Trending Topics Vs Agenda-Setting:Pengaruh Trending Topics Politik sebagai Reversed Agenda-Setting dan Haluan Politik Pemilik Terhadap Berita Politik di Televisi. Jurnal Komunikasi Indonesia, 5(1), 5-15. https://doi.org/10.7454/jki.v5i1.8895

Pramono, H., Fatchiya, A., \& Sadono, D. (2017). Kompetensi Penyuluh Tenaga Harian Lepas Tenaga Bantu Penyuluh Pertanian di Kabupaten Garut, Jawa Barat. Jurnal Penyuluhan, 13(2). https://doi.org/https://doi.org/10.25015/penyuluhan.v13i2.16128

Prasasti, S., \& Prakoso, E. T. (2020). Karakter dan Perilaku Milineal: Peluang atau Ancaman Bonus Demografi. Jurnal Ilmiah Bimbingan Dan Konseling, 3(1), 10-22. https://doi.org/https://doi.org/10.33369/consilia.v3i1.11981

Prayoga, K. (2018). Dampak Penetrasi Teknologi Informasi Dalam Transformasi Sistem Penyuluhan Pertanian Di Indonesia. JSEP (Journal of Social and Agricultural Economics), 11(1), 46. https://doi.org/10.19184/jsep.v11i3.5663

Praza, R. (2016). Optimalisasi Cyber Extension dalam Pembangunan Pertanian di Era MEA. Prosiding Seminar Nasional BKS PTN Wilayah Barat Bidang Ilmu Pertanian., August 2016, 200-204. http://repository.unimal.ac.id/2913/1/Optimalisasi Cyber Extension Dalam Pembangunan.pdf

Purwatiningsih, N. A., Fatchiya, A., \& Mulyandari, R. S. H. (2018). Pemanfaatan Internet dalam Meningkatkan Kinerja Penyuluh Pertanian di Kabupaten Cianjur. Jurnal Penyuluhan, 14(1). https://doi.org/10.25015/penyuluhan.v14i1.17173

Rahardjo, W., Qomariyah, N., Andriani, I., Hermita, M., \& Zanah, F. N. (2020). Adiksi Media Sosial pada Remaja Pengguna Instagram dan WhatsApp: Memahami Peran Need Fulfillment dan Social Media Engagement. Jurnal Psikologi Sosial, 18(1), 5-16. https://doi.org/10.7454/jps.2020.03

Sabir, Sugiyanto, K, S., \& Y, Y. (2018). Analisis Tingkat Kinerja Penyuluh Pertanian Dalam Pemanfaatan Cyber Extension Di Wilayah Malang Raya. Jurnal Agriekstensia, 17(1). https://doi.org/https://doi.org/10.34145/agriekstensia.v17i1.70

Sapar, Jahi, A., Asngari, P. S., Amiruddin, \& Purnaba, I. . P. (2012). Kinerja Penyuluh Pertanian dan Dampaknya pada Kompetensi Petani Kakao di Empat Wilayah Sulawesi Selatan. Jurnal Penyuluhan, 8(1), 29-41. https://doi.org/https://doi.org/10.25015/penyuluhan.v8i1.9892

Sayre, B., Bode, L., Shah, D., Wilcox, D., \& Shah, C. (2010). Agenda Setting in a Digital Age: Tracking Attention to California Proposition 8 in Social Media, Online News \& Conventional News. Policy \& Internet, 2(2), 7-32. https://doi.org/10.2202/1944-2866.1040

Siswanto, D. (2012). Hakikat Penyuluhan Pembangunan dalam Masyarakat. Jurnal Filsafat, 22(1), 51-68. https://doi.org/10.22146/jf.12985

Sumardjo. (1999). Transformasi Model Penyuluhan Pertanian Menuju Pengembangan Kemandirian Petani (Kasus di Propinsi Jawa Barat) [disertasi] (pp. 1-372). [Disertasi] Institut Pertanian Bogor.

Sumardjo. (2010). Penyuluhan Menuju Pengembangan Kapital Manusia dan Kapital Sosial dalam Mewujudkan Kesejahteraan Rakyat. Orasi Ilmiah Guru Besar Dalam Rangka Dies Natalis IPB $\mathrm{Ke}-47,1-63$.

Sumardjo. (2017). Cyber Extension: Masalah Dan Tantangan Dalam Pembangunan Pertanian. Kuliah Umum 23 November 2017, 1-16. https://doi.org/10.1017/CBO9781107415324.004

Sumardjo. (2019). Sinergi Penyuluhan dan Komunikasi Pembangunan di Era Komunikasi Digital dalam Mewujudkan Kesejahteraan. Prosiding Seminar Nasional Penyuluhan Dan Komunikasi Pembangunan Untuk Pemberdayaan Masyarakat (Semnas PKP-PM): "Kontribusi Ilmu Penyuluhan Dan Komunikasi Pembangunan Untuk Memperkuat Kemandirian Masyarakat Indonesia Pada Era Revolusi Industri 4.0”2 Mei, 23-52.

Surat Edaran Kepala BNN Nomor SE/83/VI/KA/KP.10/2020/ BNN tahun 2020 tentang Penyelenggaraan Sosialisasi P4GN dan Pencegahan Penyebaran Virus Covid-19 di Lingkungan 
BNN Secara Daring, (2020).

Suratini, Muljono, P., \& Wibowo, C. T. (2021). Pemanfaatan Media Sosial untuk Mendukung Kegiatan Penyuluhan Pertanian di Kabupaten Minahasa Provinsi Sulawesi Utara. Jurnal Penyuluhan, 17(01), 12-24. https://doi.org/https://doi.org/10.25015/17202132302 Pemanfaatan

Syafruddin, Hariadi, S. S., \& Wastutiningsih, S. P. (2013). Kinerja Penyuluh Pertanian Berdasarkan Faktor Personal dan Situasional. 40(2), 240-257. https://doi.org/10.22146/jpsi.6980

Syahyuti. (2014). Peran Strategis Penyuluh Swadaya dalam Paradigma Baru Penyuluhan Pertanian $\begin{array}{lllll}\text { Indonesia. Forum Penelitian Agro } & \text { Ekonomi, }\end{array}$ https://doi.org/10.21082/fae.v32n1.2014.43-58

Veronice. (2015). Analysis level of utilization information and communication technology with the competency level of extension workers. International Journal on Advanced Science, Engineering and Information Technology, 5(3), 226-229. https://doi.org/10.18517/ijaseit.5.3.533

Veronice, Yelfiarita, \& Darnetti. (2015). Analysis of characteristics extension workers to utilization of information and communication technology. International Journal on Advanced Science, Engineering and Information Technology, 5(4), 303-305. https://doi.org/10.18517/ijaseit.5.4.555

Wheeler, S. (2012). Digital literacies for engagement in emerging online cultures. ELC Researcj Paper Series, 5, 14-25.

Wijaya, A. S., Sarwoprasodjo, S., \& Febrina, D. (2019). Cyber Extension: Penggunaan Media dan Kelancaran Pencarian Informasi di Kalangan Penyuluh Pertanian Kabupaten Bogor. Jurnal KMP $\begin{array}{llll}\text { (Jurnal Komunikasi 174-123. } & \text { Pembangunan), }\end{array}$ https://doi.org/10.29244/jurnalkmp.17.2.114-123

Zhang, Y., Wang, L., \& Duan, Y. (2016). Agricultural information dissemination using ICTs: A review and analysis of information dissemination models in China. Information Processing in Agriculture, 3(1), 17-29. https://doi.org/10.1016/j.inpa.2015.11.002 